\title{
Enhanced anti-melanoma efficacy through a combination of the armed oncolytic adenovirus ZD55-IL-24 and immune checkpoint blockade in B16-bearing immunocompetent mouse model
}

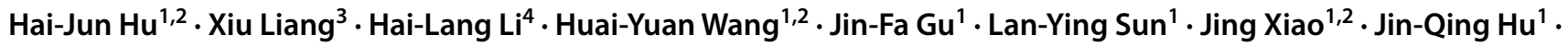 \\ Ai-Min $\mathrm{Ni}^{1} \cdot$ Xin-Yuan Liu ${ }^{1}$ (D)
}

Received: 31 August 2020 / Accepted: 14 April 2021 / Published online: 26 April 2021

(c) The Author(s) 2021

\begin{abstract}
Although the recent treatment in melanoma through the use of anti-PD-1 immunotherapy is successful, the efficacy of this approach remains to be improved. Here, we explore the feasibility of combination strategy with the armed oncolytic adenovirus ZD55-IL-24 and PD-1 blockade. We find that combination therapy with localized ZD55-IL-24 and systemic PD-1 blockade leads to synergistic inhibition of both local and distant established tumors in B16-bearing immunocompetent mouse model. Our further mechanism investigation reveals that synergistic therapeutic effect is associated with marked promotion of tumor immune infiltration and recognition in both local and distant tumors as well as spleens. PD-1 blockade has no obvious effect on promotion of tumor immune infiltration and recognition. Localized therapy with ZD55-IL-24, however, can help PD-1 blockade to overcome the limitation of relatively low tumor immune infiltration and recognition. This study provides a rationale for investigation of such combination therapy in the clinic.
\end{abstract}

Keywords Melanoma Oncolytic virus · PD-1 blockade $\cdot$ Combination therapy $\cdot$ Tumor immune infiltration $\cdot$ Tumor immune recognition

\section{Introduction}

Hai-Jun Hu and Xiu Liang have contributed equally to this work.

Hai-Jun $\mathrm{Hu}$

huhaijun2015@sibcb.ac.cn

$\triangle$ Ai-Min Ni

aimin.ni@sibcb.ac.cn

$\triangle$ Xin-Yuan Liu

xyliu@sibcb.ac.cn

1 State Key Laboratory of Cell Biology, Shanghai Institute of Biochemistry and Cell Biology, Center for Excellence in Molecular Cell Science, Chinese Academy of Sciences, Shanghai 200031, China

2 University of Chinese Academy of Sciences, Beijing 100049, China

3 School of Life Sciences and Technology, Tongji University, Shanghai 200092, China

4 Department of Pharmacy, Xiamen Medical College, Xiamen 361023, China
Melanoma, the most aggressive type of skin cancer, has a poor prognosis, with a median overall survival of 8-10 months and a 5-year survival rate of $20 \%$ [1]. Even with early diagnosis, melanoma still exhibits a poor prognosis because of its rapid proliferation, and therapy remains challenging for physicians [2]. In the past several years, five breakthrough anti-melanoma agents have been approved by the US Food and Drug Administration (FDA). These agents include small-molecule inhibitors of BRAF and MEK, immunotherapeutic antibodies directed at cytotoxic T lymphocyte-associated protein 4 (CTLA-4) and programmed cell death protein 1 (PD-1), and the modified oncolytic herpes virus T-VEC [3]. Recent studies suggest that anti-PD-1 therapy showed the best outcomes among the current melanoma therapeutic agents and, therefore, it is considered as the current best anti-melanoma drug [4]. However, the dramatic responses of anti-PD-1 therapy are confined to a minority of patients, and most treated patients still succumb to progressive disease [5]. Therefore, although the current treatments for melanoma have been successful, to cure or make 
melanoma manageable chronic, more effective drugs or therapeutic strategies are still needed.

To address the above issue, there is currently much enthusiasm for combining anti-PD-1 therapy with other cancer treatment modalities [6-8]. CTLA-4 and PD-1 inhibit antitumor immune responses by different mechanisms; consistent with preclinical studies that demonstrated synergistic effects of combined anti-CTLA-4 with anti-PD-1 therapy, a phase III clinical trials demonstrated that combination therapies led to improved responses in patients with metastatic melanoma [9]. Another compelling strategy is combination of immune checkpoint inhibitors with T-VEC. Recent studies indicated that the efficacy of anti-PD-1 antibodies was largely confined to patients with tumors that have robust baseline $\mathrm{CD} 8^{+} \mathrm{T}$ cell infiltrates [10], and the modified oncolytic herpes virus T-VEC could enhance the immunogenicity of melanomas for which baseline immune recognition was lacking or not robust [3]. Preliminary reports have described high response rates in patients with advanced-stage melanoma treated using the combination of anti-PD-1 therapy and T-VEC therapy [3, 11]. Thereby, it is reasonable to suggest that a combination of complementary therapeutic strategies has a better chance of success.

Oncolytic viruses are self-amplifying cancer biotherapeutics that destroy cancerous tissues without causing harm to normal tissues [12]. ZD55 is an E1B 55-kDa gene-deleted adenovirus that is similar to the famous oncolytic adenovirus ONYX-015, but with the marked difference of a cloning site to insert foreign genes [13]. Another two differences between ZD55 and other oncolytic adenoviruses are that ZD55 is an adenovirus type 5 homozygote and has an intact E3 region, whereas the most of other oncolytic adenoviruses either are adenovirus chimeras (e.g., ONYX-015 is a type $2 / 5$ chimera and Colo-Ad1 is a type 11/3 chimera) [12-14] or have major deletions within the E3 region (e.g., ONYX-015, H101 and CG0070) $[12,14,15]$. Based on our tumor-targeting replicative viral vector ZD55, we constructed ZD55-IL-24 by inserting the exogenous antitumor gene mda-7/interleukin-24 (IL24) gene into the cloning site of ZD55 [16]. ZD55-IL-24 was one of the most effective armed oncolytic viruses we have found yet [17]. Our previous results have shown that ZD55IL-24 was superior to ONYX-015 and the replication-defective adenovirus carrying the IL-24 gene [16, 18-20]. In this study, we further investigated whether ZD55-IL-24 therapy in combination with PD-1 immune checkpoint inhibition could facilitate primary tumor as well as metastatic lesions rejection in B16-bearing immunocompetent mouse model.

\section{Materials and methods}

\section{Antibodies}

Therapeutic anti-PD-1 (BE0146) and isotype control antibody (BE0089) were produced by BioXcell. Antibodies used for flow cytometry were purchased from eBioscience (Anti-mouse CD3ع FITC, CD11b eFluor 660) and Biolegend (Anti-mouse CD8a Alexa Fluor ${ }^{\circledR}$ 647, NK 1.1 Alexa Fluor ${ }^{\circledR}$ 647, Ly-6G/Ly-6C (Gr-1) Alexa Fluor® 488, CD19 FITC, CD45R/B220 Alexa Fluor® 647, F4/80 Alexa Fluor® 488, CD206 Alexa Fluor® 647, FOXP3 Alexa Fluor ${ }^{\circledR} 488$, CD4 Alexa Fluor ${ }^{\circledR} 647$, CD11c Alexa Fluor ${ }^{\circledR} 488$, I-A/I-E Alexa Fluor® 647, CD16/32).

\section{Cells}

All the cell lines used in this study were obtained from the Cell Bank of the Type Culture Collection of the Chinese Academy of Sciences (Shanghai, China). HEK293 cell was a human embryonic kidney cell line, transformed with Ad5 E1. B16 was the murine melanoma cell line. The HEK293 cell line was cultured in DMEM (Gibco, 11995-073), and B16 cell line was cultured in RPMI-1640 (Gibco, 11875093). Media were supplemented with $10 \%$ FBS (Gibco, 10270-106), $50 \mathrm{U} / \mathrm{mL}$ penicillin and $50 \mu \mathrm{g} / \mathrm{mL}$ streptomycin. All cell lines were maintained at $37^{\circ} \mathrm{C}$ with $5 \% \mathrm{CO}_{2}$ and tested to ensure that they were free of mycoplasma contamination [21].

\section{Adenoviruses}

The recombinant adenoviruses ZD55-IL-24 used in this study have been previously described $[13,16]$. Briefly, ZD55 is a conditionally replicating adenovirus type 5 with E1B (55-kDa)-deleted and ZD55-IL-24 is a foreign human IL-24 gene-inserted ZD55 expressing IL-24. ZD55-IL-24 was propagated in $\mathrm{HEK} 293$ cells and purified by $\mathrm{CsCl}$ equilibrium centrifugation. Virus titers were determined by TCID50 assay using HEK293 cells and converted to plaqueforming units (PFU). The titer of ZD55-IL-24 was adjusted to $1.5 \times 10^{10} \mathrm{PFU} / \mathrm{mL}$ and was administered intratumorally at $50 \mu \mathrm{L} /$ dose.

\section{Mice}

All mice were obtained from Shanghai Laboratory Animal Center, Chinese Academy of Sciences (SLAC) (Shanghai, China) and maintained at $\leq 5$ mice per cage under specific pathogen-free conditions in the Animal Care Facility of Shanghai Institute of Biochemistry and Cell Biology, 
Chinese Academy of Sciences. Mice were provided with water and rodent chow, and maintained under a regular $12 \mathrm{~h} / 12 \mathrm{~h}$ light/dark schedule at a constant room temperature $\left(22 \pm 2{ }^{\circ} \mathrm{C}\right)$. The responsible veterinarian was in charge of the diagnosis, treatment, and control of diseases in the animal facilities. All animal procedures were performed in strict accordance with the institutional guidelines and were approved by the Institutional Animal Care and Use Committee of Shanghai Institute of Biochemistry and Cell Biology, Chinese Academy of Sciences. Special attention was taken to determine the humane end points and to decide whether the mice should be euthanized in order to avoid further suffering. According to the 3 Rs principle, experiments were carefully designed to minimize the use of mice and to obtain maximum amount of data. Animal experiments were reported in accordance with the ARRIVE guidelines [22].

\section{Flow cytometry}

Cells isolated from tumors or spleens were processed for surface labeling with appropriate antibodies. Propidium iodide was used to distinguish the live cells. FOXP3 was stained using the True-Nuclear ${ }^{\mathrm{TM}}$ Transcription Factor Buffer Set (424401) from Biolegend. Data were acquired using the Beckman CytoFLEX Flow Cytometer and analyzed using FlowJo software.

\section{Local tumor therapy experiment}

Female C57BL/6 mice 6 weeks of age were obtained from SLAC and quarantined for 2 weeks before tumor implantation. An inoculum of $1 \times 10^{6} \mathrm{~B} 16$ cells was injected subcutaneously on the right flank of mice in $100 \mu \mathrm{L}$ sterile PBS. When the subcutaneous tumor xenograft size reached about $80 \mathrm{~mm}^{3}$ (Day 8), the mice were randomized into four groups using R software, and treatments were initiated as indicated in Fig. 1a. ZD55-IL-24 was administered intratumorally at $50 \mu \mathrm{L}$ per dose $\left(7.5 \times 10^{8} \mathrm{PFU} /\right.$ dose $)$. Anti-PD- 1 was administered intraperitoneally at $200 \mu \mathrm{g}$ per dose in a volume of $100 \mu \mathrm{L}$ antibody dilution buffer (BioXcell, IP0070). Tumor size $\left(\right.$ Volume $=$ length $\times$ width $\left.^{2} \times 0.5\right)$ and body weight were measured every 2 days, and mice were euthanized when the average tumor volume of PBS group exceeded 2,000 $\mathrm{mm}^{3}$. Photographs of the tumors resected from the sacrificed mice were taken immediately.

\section{Distant tumor therapy experiment}

Female C57BL/6 mice 6 weeks of age were obtained from SLAC and quarantined for 2 weeks before tumor implantation. Tumors were implanted by injection of $1 \times 10^{6} \mathrm{~B} 16$ cells in the right flank intradermally on day 0 and $2 \times 10^{5}$ B 16 cells in the left flank on day 4 . When the average right flank tumor xenograft size reached about $80 \mathrm{~mm}^{3}$ (Day 11), the mice were randomized into 6 groups using R software, and treatments were initiated as indicated in Fig. 3a. ZD55IL-24 was administered intratumorally at $50 \mu \mathrm{L}$ per dose $\left(7.5 \times 10^{8} \mathrm{PFU} /\right.$ dose $)$. Anti-PD-1 and isotype control antibody were administered intraperitoneally at $200 \mu \mathrm{g}$ per dose in a volume of $100 \mu \mathrm{L}$ antibody dilution buffer (BioXcell, IP0070). Tumor size $\left(\right.$ Volume $=$ length $\times$ width $\left.^{2} \times 0.5\right)$ as well as body weight were measured every 2 days, and mice were euthanized when the average right tumor volume of PBS group exceeded 2,000 $\mathrm{mm}^{3}$. Animal survival was also recorded every 2 days.

\section{Statistical analyses}

Statistical analyses were performed using GraphPad Prism 6.0. Comparisons between two groups were performed using Student's t-test. Comparison of multiple groups was performed by analysis of variance (ANOVA). Survival curves were analyzed using log-rank (Mantel-Cox) test. Differences were considered significant at $P<0.05$ $(* P<0.05, * * P<0.01, * * * P<0.001, * * * * P<0.0001, \mathrm{NS}$, not significant).

\section{Results}

\section{Synergistic effect of ZD55-IL-24 and PD-1 blockade in primary tumors}

To examine the feasibility and efficacy of ZD55-IL-24 therapy combined with anti-PD-1 therapy, we compared monotherapy with ZD55-IL-24 alone, or anti-PD-1 alone versus dual therapy with ZD55-IL-24 plus anti-PD-1 in B16-bearing immunocompetent mouse model. B16 melanoma cells $\left(10^{6}\right)$ were injected subcutaneously (s.c.) to the right flank of C57BL/6 mice and allowed to grow for 8 days before initiation of therapy, resulting in tumor sizes of $\sim 80 \mathrm{~mm}^{3}$ at the initial time of treatment. ZD55-IL-24 was administered intratumorally (i.t.), and anti-PD-1 antibody was injected intraperitoneally (i.p.). Therapies were given every 3 days, with both ZD55-IL-24 and anti-PD-1 antibody being administered four times (Fig. 1a).

Although the therapeutic effects were observed in both monotherapies, especially the robust therapeutic effect of ZD55IL-24 therapy alone, the combined therapy further slowed the growth of established B16 melanomas compared with either therapy alone (Fig. 1b). The tumor volume and weight in the combination therapy group were $371.5379 \pm 84.83121$ $\mathrm{mm}^{3}$ and $0.3 \pm 0.09189 \mathrm{~g}$, whereas the PBS-treated group was $2122.229 \pm 261.3108 \mathrm{~mm}^{3}$ and $2.743 \pm 0.5291 \mathrm{~g}$, the ZD55-IL-24-treated group was $830.6364 \pm 167.3815 \mathrm{~mm}^{3}$ and $1.2 \pm 0.2737 \mathrm{~g}$, and the anti-PD-1-treated group was 


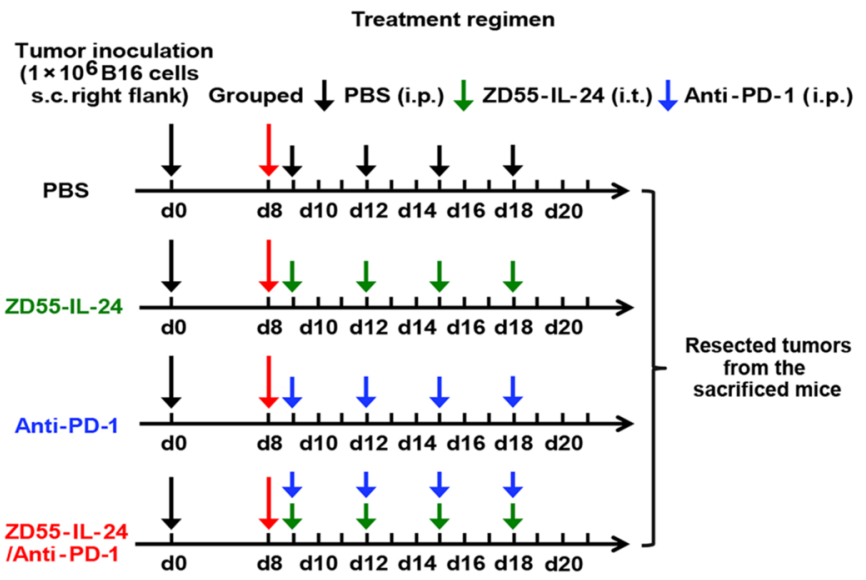

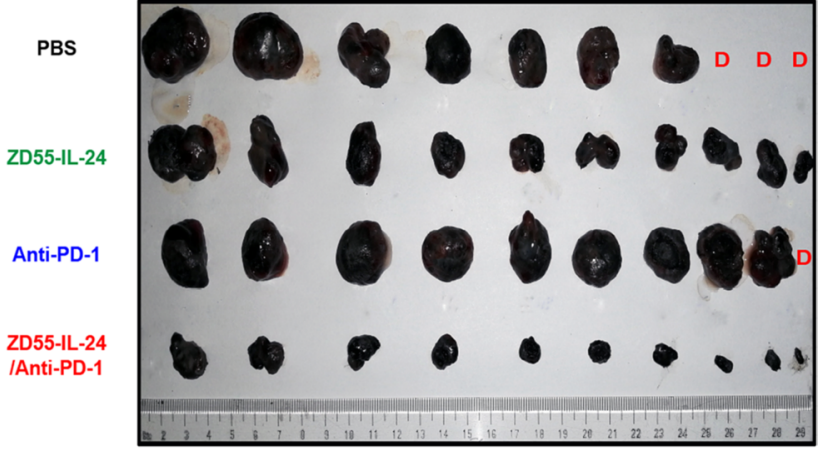

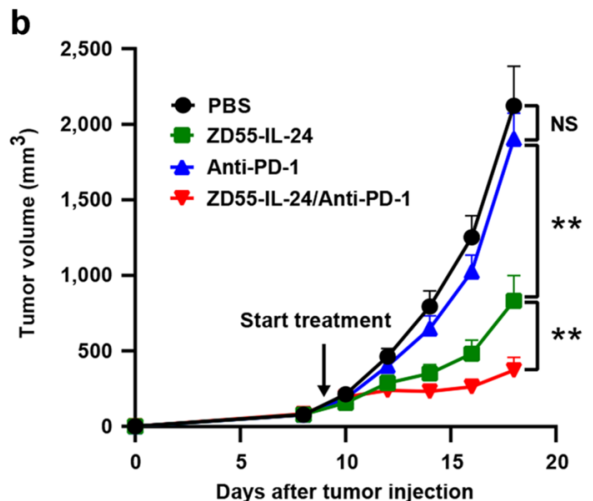

d

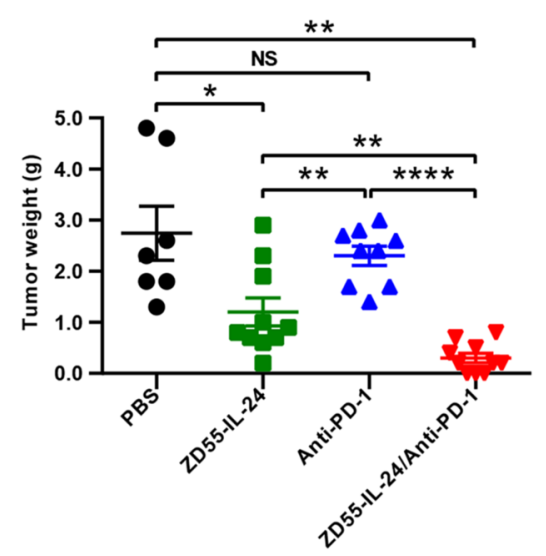

e

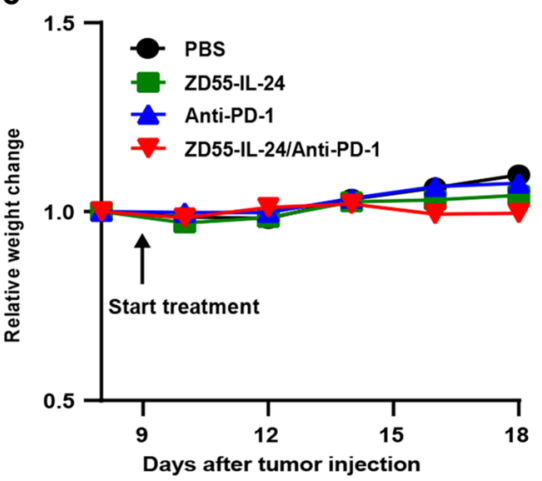

Fig. 1 ZD55-IL-24 synergizes with PD-1 blockade to reject local established melanomas in B16-bearing immunocompetent mouse model. C57BL/6 mice were inoculated with $1 \times 10^{6} \mathrm{~B} 16$ melanoma cells s.c. in the right flank and treated $9 \mathrm{~d}$ later (the average tumor volume was about $\left.80 \mathrm{~mm}^{3}\right)$ with PBS, anti-PD-1 antibody $(0.2 \mathrm{mg} /$ dose), ZD55-IL-24 $\left(7.5 \times 10^{8} \mathrm{PFU} /\right.$ dose $)$, or the combination via intraperitoneal or intratumoral injection as indicated. a Scheme of tumor engraftment and treatments. b In vivo tumor growth curves. c Photograph of tumors resected from the sacrificed mice at the end of the experiment. d Weight of tumors resected from the sacrificed mice at the end of the experiment. e Body weight changes of mice monitored during the therapy period. s.c. subcutaneous injection, i.t. intratumoral injection, i.p. intraperitoneal injection, $D$ Death, $n=10$ C57BL/6 mice per group. Data are presented as Mean \pm SEM
$1903.805 \pm 169.4441 \mathrm{~mm}^{3}$ and $2.3 \pm 0.1878 \mathrm{~g}$. The tumors of the combination treatment group were significantly smaller than the tumors in the other groups (Fig. 1c, d), indicating that the synergistic potential of ZD55-IL-24 and PD-1 blockade. Of note, despite high anti-melanoma efficacy, the combination of ZD55-IL-24 and PD-1 blockade was associated with no significant systemic toxicity, as mice did not show significant weight or hair loss (Fig. 1e).

\section{ZD55-IL-24 can improve the low tumor immune infiltration in primary tumors of the anti-PD-1-treated mice}

To understand the mechanism of improved anti-melanoma efficacy with the combination therapy, we analyzed cellular infiltrates in treated tumors using flow cytometry. Compared with the PBS control group, the anti-PD-1 therapy only group had no significant effect on the promotion of tumor immune infiltration in local tumors (Fig. 2d, h). In contrast, a substantial increase of tumor immune infiltration was observed in the ZD55-IL-24 monotherapy group. The combination therapy showed an enhanced tumor immune infiltration compared with anti-PD-1 therapy alone, albeit no further enhancement compared with ZD55-IL-24 therapy alone (Fig. 2d, h). The enhanced immune infiltrates in primary tumors were characterized by increase in innate immune compartment, including overall myeloid cells, neutrophils, natural killer T (NKT) cells, M1 macrophages and M2 macrophages (Fig. 2a-d), and the adaptive compartment, including overall $T$ cells, 
a

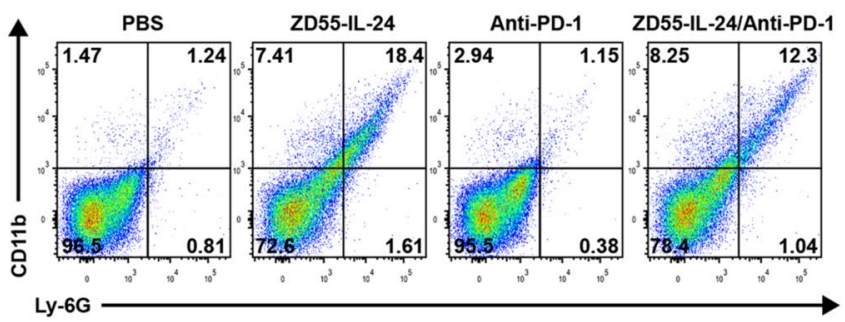

C

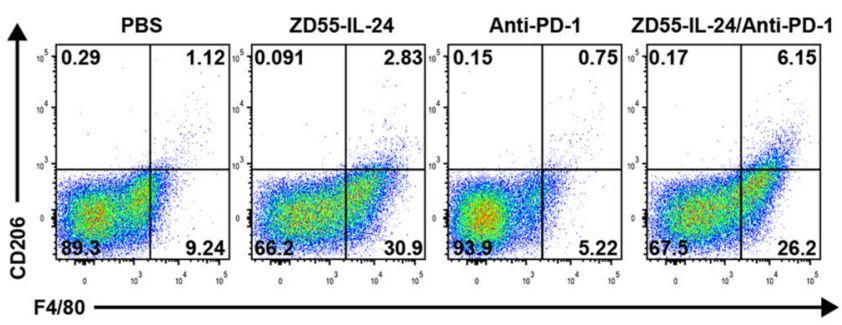

e

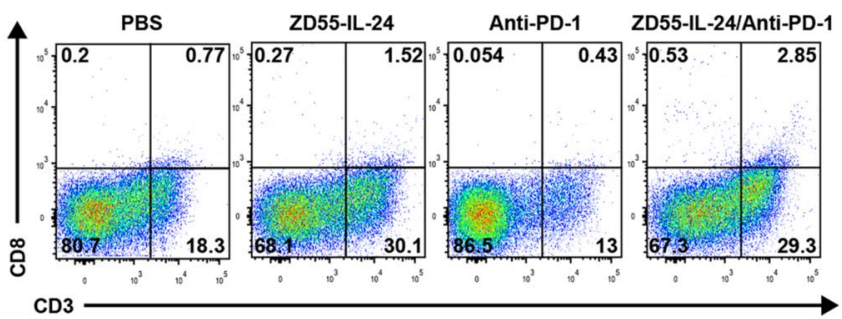

g

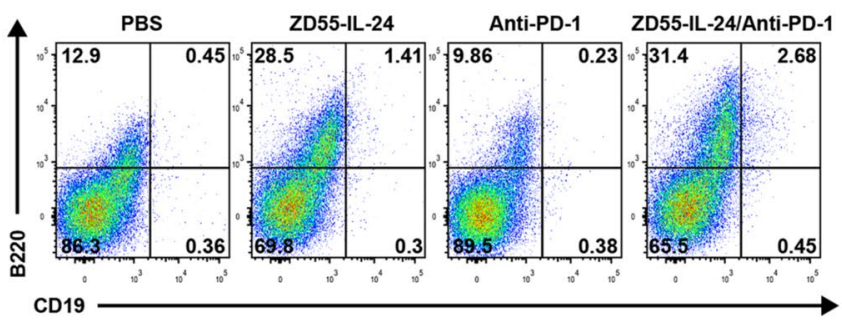

Fig. 2 ZD55-IL-24 helps PD-1 blockade to overcome the limitation of relatively low tumor immune infiltration in local established tumors. C57BL/6 mice were treated as indicated in Fig. 1a, and then the tumor cells were isolated for flow cytometry analysis. Tumor immune infiltration of innate immune cells in local tumors. a Representative flow cytometry plots of tumor-infiltrating total myeloid cells $\left(\mathrm{CD} 11 \mathrm{~b}^{+}\right)$and neutrophils $\left(\mathrm{CD} 11 \mathrm{~b}^{+} \mathrm{Ly}-6 \mathrm{G}^{+} \mathrm{Ly}-6 \mathrm{C}^{\text {low }}\right)$. b Representative flow cytometry plots of tumor-infiltrating NK cells $\left(\mathrm{NK} 1.1^{+} \mathrm{CD}^{-}\right)$and NKT cells $\left(\mathrm{NK} 1.1^{+} \mathrm{CD}^{+}\right)$. c Representative flow cytometry plots of tumor-infiltrating $\mathrm{M} 1$ macrophages $\left(\mathrm{F} 4 / 80^{+} \mathrm{CD} 206^{-}\right)$and $\mathrm{M} 2$ macrophages $\left(\mathrm{F} 4 / 80^{+} \mathrm{CD} 206^{+}\right)$. d Percent- b
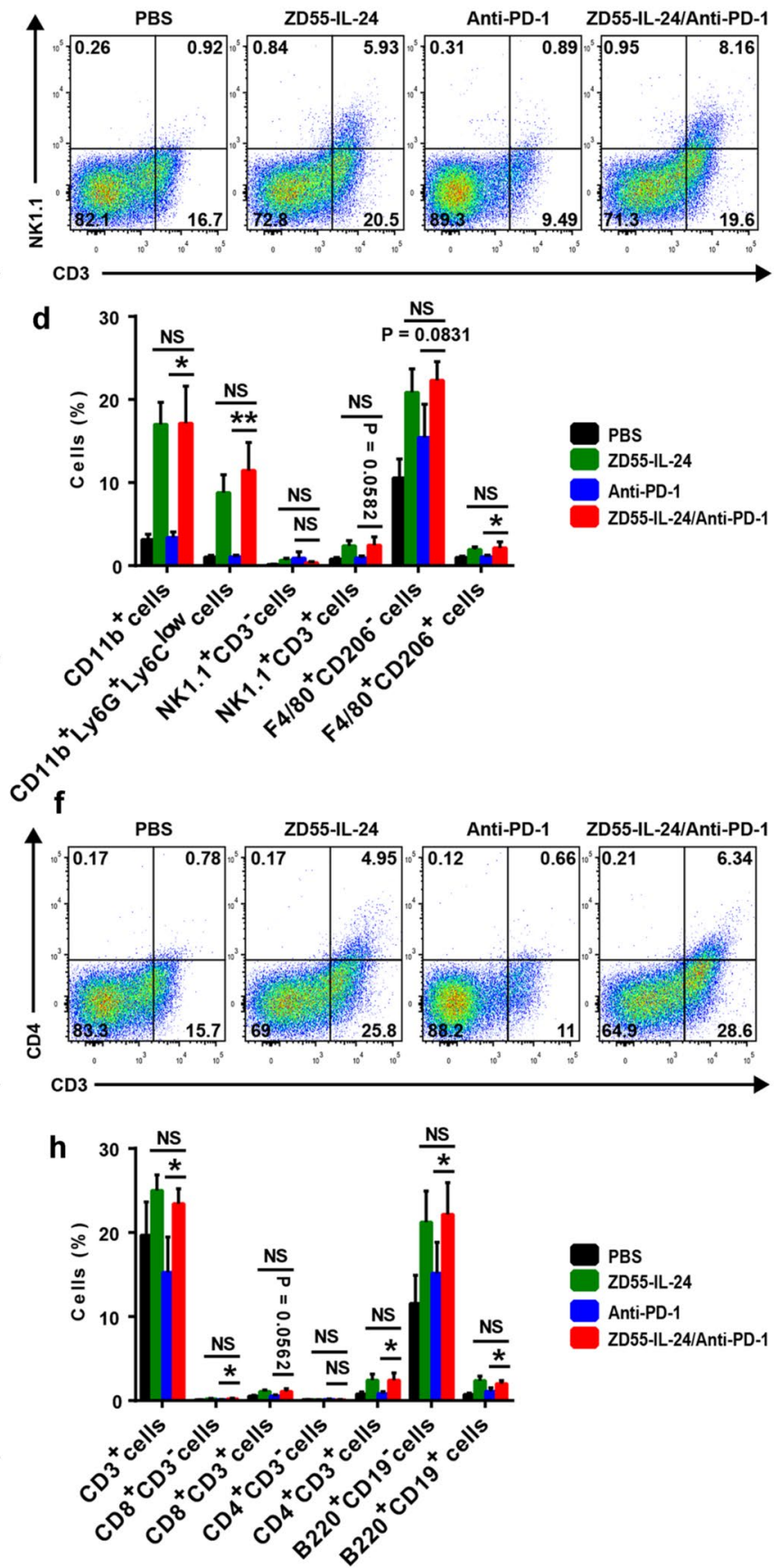

ages of various innate immune cells in local tumors. Tumor immune infiltration of adaptive immune cells in local tumors. e Representative flow cytometry plots of tumor-infiltrating total $T$ cells $\left(\mathrm{CD}^{+}\right)$, $\mathrm{CD}^{+} \mathrm{CD}^{-}$cells and $\mathrm{CD}^{+} T$ cells $\left(\mathrm{CD}^{+}{ }^{+} \mathrm{CD} 3^{+}\right)$. f Representative flow cytometry plots of tumor-infiltrating $\mathrm{CD}^{+}{ }^{+} \mathrm{CD} 3^{-}$cells and $\mathrm{CD} 4^{+}$ $T$ cells $\left(\mathrm{CD}^{+} \mathrm{CD}^{+}\right)$. $\mathrm{g}$ Representative flow cytometry plots of tumorinfiltrating plasma cells $\left(\mathrm{B} 220^{+} \mathrm{CD} 19^{-}\right)$and $\mathrm{B}$ cells $\left(\mathrm{B} 220^{+} \mathrm{CD} 19^{+}\right)$. h Percentages of various adaptive immune cells in local tumors. Mean \pm SEM is shown. Data represent cumulative results from seven independent experiments 
a

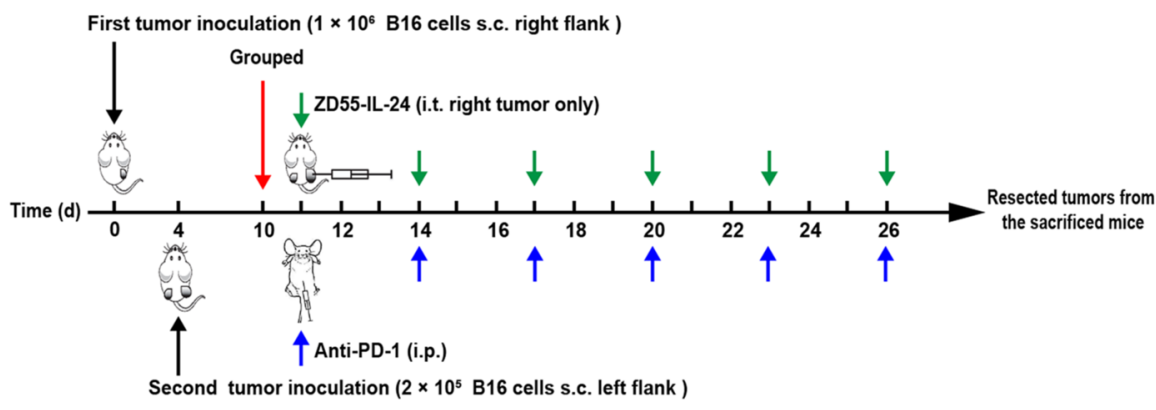

C

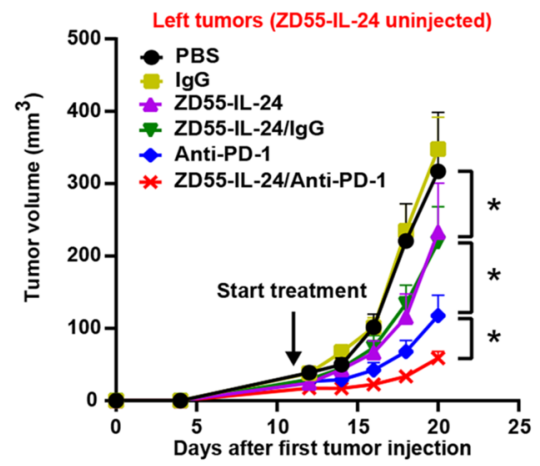

f

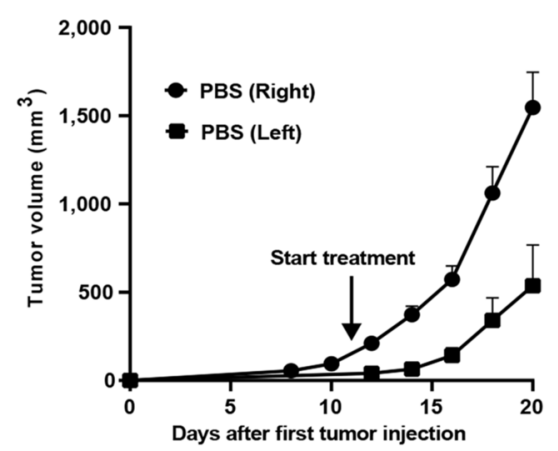

i

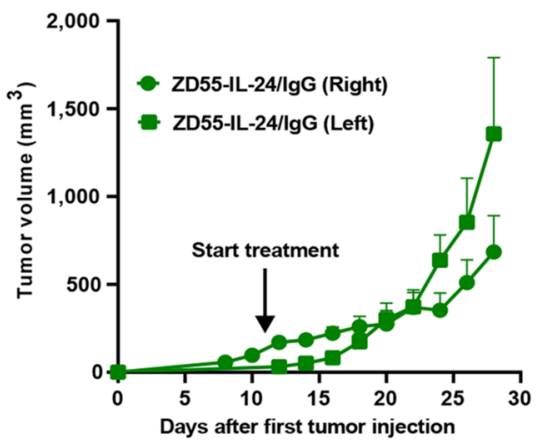

d

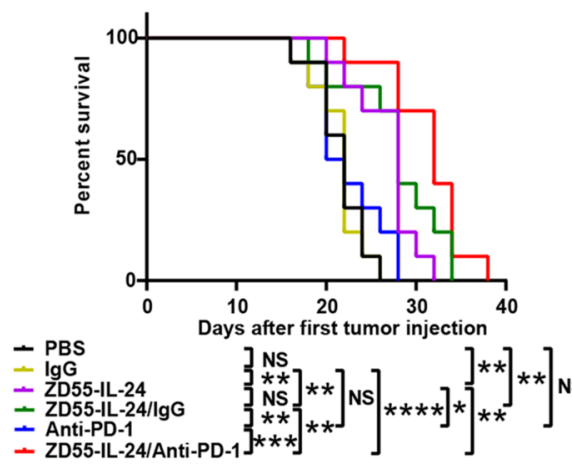

g

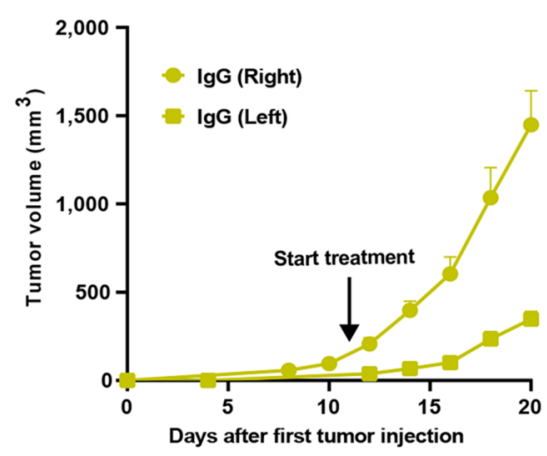

j

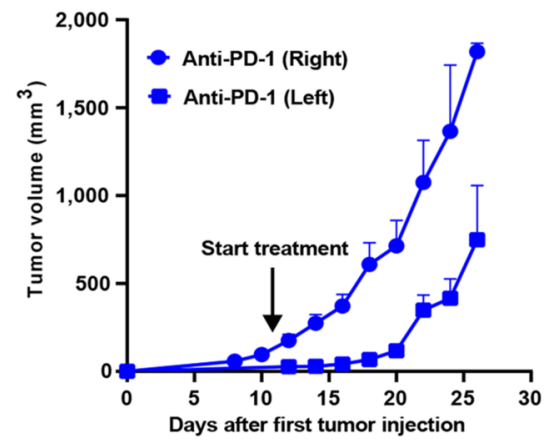

b
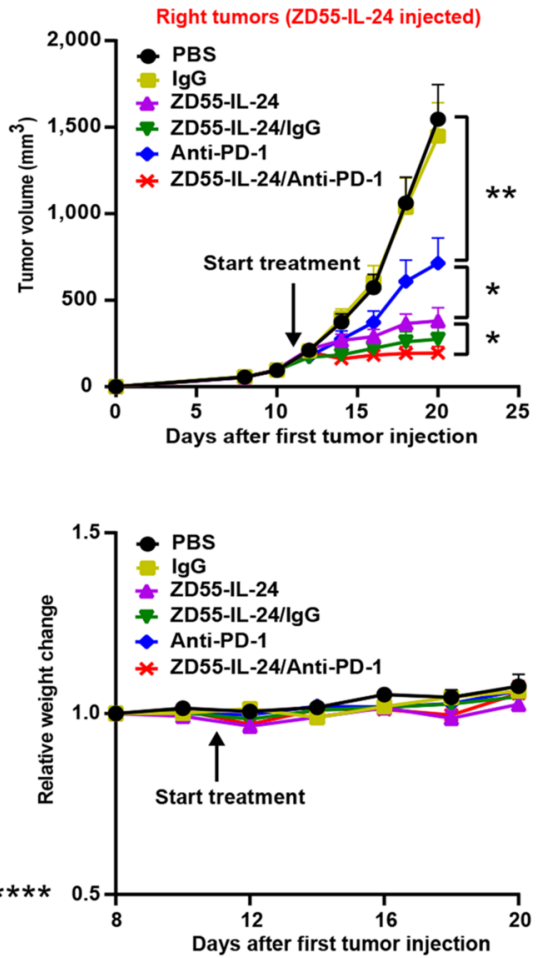

h

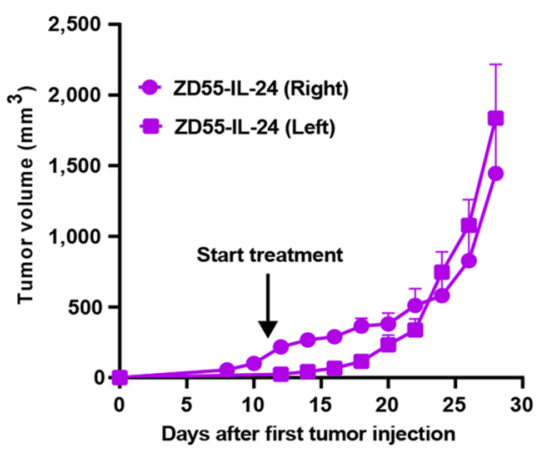

k

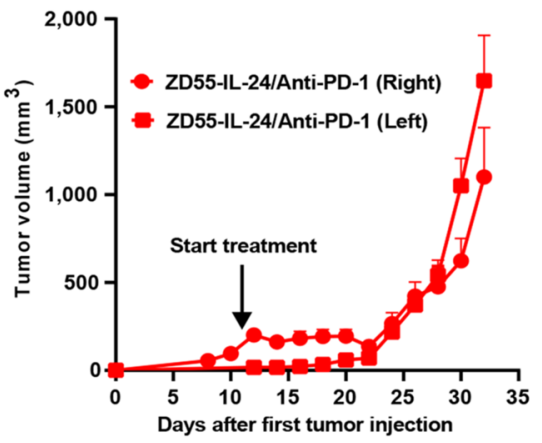

$\mathrm{CD} 8^{+} \mathrm{CD} 3^{-}$cells, $\mathrm{CD}^{+}{ }^{+} \mathrm{T}$ cells, $\mathrm{CD} 4^{+} T$ cells, plasma cells and $\mathrm{B}$ cells (Fig. 2e-h). Among the above immune cells, the antitumor effect of neutrophils, NKT cells, M1 macrophages, $\mathrm{CD} 8^{+} T$ cells and $\mathrm{CD} 4^{+} T$ cells has been well-documented [5, 23-27]. These results indicated that ZD55-IL-24 was able to help PD-1 blockade to overcome the weakness of relatively low tumor immune infiltration in primary tumors. 
4Fig. 3 ZD55-IL-24 also synergizes with PD-1 blockade to reject distant uninjected melanomas in B16-bearing immunocompetent mouse model. C57BL/6 mice were inoculated with $1 \times 10^{6} \mathrm{~B} 16$ cells s.c. in the right flank on day 0 and $2 \times 10^{5}$ B16 cells s.c. in the left flank on day 4. The B16-bearing C57BL/6 mice were subsequently treated with PBS, isotype $\operatorname{IgG}(0.2 \mathrm{mg} /$ dose $)$, anti-PD-1 antibody $(0.2 \mathrm{mg} /$ dose), ZD55-IL-24 $\left(7.5 \times 10^{8} \mathrm{PFU} /\right.$ dose $)$, or the combination via intraperitoneal or intratumoral injection as indicated, starting when the average tumor volume was about $80 \mathrm{~mm}^{3}$. a Scheme of tumor engraftment and treatments. b Growth of local ZD55-IL-24-injected (right flank) and $\mathbf{c}$ distant ZD55-IL-24-uninjected (left flank) tumors. d Overall survival. e Body weight changes of the mice monitored during the therapy period. $\mathbf{f}$ Local and distant tumor growth curves of Group PBS, $\mathbf{g}$ Group IgG, h Group ZD55-IL-24, i Group ZD55IL-24/IgG, $\mathbf{j}$ Group anti-PD-1 and $\mathbf{k}$ Group ZD55-IL-24/anti-PD-1, respectively. s.c. subcutaneous injection, i.t. intratumoral injection, i.p. intraperitoneal injection, $n=10 \mathrm{C} 57 \mathrm{BL} / 6$ mice per group. Data are presented as Mean \pm SEM

Given the negative role of regulatory $T\left(T_{\text {reg }}\right)$ cells in antitumor immunity $[28,29]$, we next further analyzed the infiltration of $T_{\text {reg }}$ cells in local established tumors and calculated the conventional CD $4^{+} \mathrm{FoxP}^{-} T\left(T_{\text {conv }}\right)$ cells to $T_{\text {reg }}$ cells ratio, which has been previously demonstrated to be a marker of a favorable immunological response to immunotherapy $[23,30]$. Both ZD55-IL-24 only and PD-1 blockade only caused a significant enhancement of $T_{\text {reg }}$ cells in local tumors compared with the PBS control group, and the B16 tumors treated with combination therapy showed a further higher accumulation of $T_{\text {reg }}$ cells than those tumors treated by PD-1 blockade alone, albeit no further higher accumulation than ZD55-IL-24 therapy alone (Supplementary Figure $1 \mathrm{a}, \mathrm{b})$. Although there is a significant increase in the percentages of $T_{\text {reg }}$ cells which suppressed tumor-specific immune responses in ZD55-IL-24 therapy alone, anti-PD-1 therapy alone and the combination therapy groups, there is also a substantial increase in the percentages of $T_{\text {conv }}$ cells, with marked enhancement of the CD4 effector to $T_{\text {reg }}$ ratio (Supplementary Figure 1a, c), suggesting that both ZD55-IL-24 treatment and anti-PD-1 treatment can elicit substantial remodeling of the immunosuppressive tumor microenvironment with contributions to the immunotherapy. However, the $T_{\text {conv }} / T_{\text {reg }}$ ratio of the combination treatment group did not show statistically significant differences compared to ZD55-IL-24 therapy alone or anti-PD-1 therapy alone groups (Supplementary Figure 1a, c), suggesting that ZD55-IL-24 was unable to help PD-1 blockade to further improve the tumor immune microenvironment.

\section{Synergistic effect of ZD55-IL-24 and PD-1 blockade in distant tumors}

Motivated by the synergy observed between ZD55-IL-24 and PD-1 blockade in local tumors, we further sought to evaluate whether ZD55-IL-24 was also able to synergize with PD-1 blockade to reject the distant uninjected tumors in B16-bearing immunocompetent mouse model using a bilateral flank B16 tumor model [23]. We inoculated $1 \times 10^{6}$ B16 melanoma cells into the right flank of C57BL/6 mice intradermally on day 0 , and four days later the mice were challenged with a second injection of $2 \times 10^{5} \mathrm{~B} 16$ melanoma cells in the left flank (Fig. 3a). Six fractionated doses of ZD55-IL-24 (7.5 $\times 10^{8}$ PFU/dose) and anti-PD-1 (0.2 mg/ dose) were administered intratumorally or intraperitoneally every other two days. ZD55-IL-24 was selectively applied only to the right flank tumor lesions (local tumor), while a contralateral tumor was set without ZD55-IL-24 injection (distant tumor).

In the bilateral flank B16 tumor model, ZD55-IL-24 treatment in combination with PD-1 blockade significantly slowed not only local (Fig. 3b) but also distant (Fig. 3c) tumor growth compared to untreated or animals receiving isotype IgG, ZD55-IL-24 or anti-PD-1 monotherapy, or combination therapy with ZD55-IL-24 and isotype IgG. Consistent with the tumor growth data, the survival of mice receiving ZD55-IL-24 plus anti-PD-1 therapy was significantly prolonged compared with other treatments, although the ZD55-IL-24 monotherapy and ZD55-IL-24 plus isotype IgG therapy were also able to greatly prolong the shortened lifespan of mice (Fig. 3d). In addition, we did not observe any obvious toxicity such as weight or hair loss in mice receiving combination treatment in the bilateral flank B16 tumor model as well (Fig. 3e). These data collectively showed that the combined therapy with ZD55-IL-24 and PD-1 blockade improved antitumor responses against not only local but also distant B16 tumors in B16-bearing immunocompetent mouse model. Intriguingly, we noticed that the distant tumors grew considerably faster than local tumors in the ZD55-IL-24, ZD55-IL-24/IgG and ZD55-IL-24/antiPD-1 groups, whereas the growth of local and distant tumors was practically identical in the PBS, IgG and anti-PD-1 groups (Fig. 3f-k), indicating that ZD55-IL-24 appeared much more effective in local tumors than distant tumors, whereas anti-PD-1 appeared identical effective in both local and distant tumors, which was consistent with the fact that anti-PD-1 antibody was administered intraperitoneally.

\section{ZD55-IL-24 can also improve the low immune cell infiltrates in distant tumors of the anti-PD-1-treated mice}

Based on the synergistic anti-melanoma effect in distant tumors, we thus reasoned that ZD55-IL-24 also helped PD-1 blockade to overcome the weakness of relatively low immune cell infiltration in distant tumors. To further examine the infiltrating of immune cells in distant tumors, we next collected and processed distal tumors for flow cytometry analysis. Our flow cytometric results revealed that the immune cell infiltrates in distant tumors were similar to local 
tumors (Fig. 4d, h). A great increase in the innate immune compartment, which included total myeloid cells, neutrophils, natural killer (NK) cells, M1 macrophages and M2 macrophages (Fig. 4a-d), and the adaptive immune compartment, which included $\mathrm{CD} 8^{+} \mathrm{T}$ cells, $\mathrm{CD}^{+} T$ cells, plasma cells and B cells (Fig. 4e-h), was observed in distant tumors of the mice treated with ZD55-IL-24 monotherapy. However, only a modest increase in both innate and adaptive immune compartment was observed in distant tumors of the mice treated with anti-PD-1 monotherapy. As expected, the combination therapy further enhanced tumor immune infiltration in distant tumors compared with anti-PD-1 therapy alone, despite no statistically significant difference was observed when compared with ZD55-IL-24 therapy alone (Fig. 4d, h), which was in line with the observation in local tumors. Compared with the anti-PD-1 therapy group, a great increase in neutrophils, NK cells, M2 macrophages, $\mathrm{CD} 8^{+}$ $\mathrm{CD}^{-}$cells, $\mathrm{CD} 8^{+} \mathrm{T}$ cells, $\mathrm{CD} 4^{+} \mathrm{T}$ cells and $\mathrm{B}$ cells was observed in distant tumors of the mice treated with combination therapy (Fig. 4a-h). These results suggested that ZD55-IL-24 was able to help PD-1 blockade to overcome the weakness of relatively low tumor immune infiltration in not only local but also distal tumors in B16-bearing immunocompetent mouse model.

In addition, we also analyzed the infiltration of $T_{\text {reg }}$ cells in distant tumors and calculated the $T_{\text {conv }} / T_{\text {reg }}$ ratio. Unlike in local tumors, there was no significant change in $T_{\text {reg }}$ cells in distant tumors among the different treatment groups (Supplementary Figure $2 \mathrm{a}, \mathrm{b})$. The $T_{\text {conv }} / T_{\text {reg }}$ ratio, however, was significantly increased in distant tumors of the ZD55-IL-24 therapy alone, anti-PD-1 therapy alone and combination therapy groups (Supplementary Figure 2a, c), suggesting that both ZD55-IL-24 treatment and anti-PD-1 treatment can also elicit remodeling of the immunosuppressive tumor microenvironment in distant tumors with contributions to the immunotherapy of distant tumors. In agreement with what we observed in local tumors (Supplementary Figure 1a, c), the combination therapy also failed to further increase the $T_{\text {conv }} / T_{\text {reg }}$ ratio in distant tumors compared to ZD55-IL-24 therapy alone or anti-PD-1 therapy alone (Supplementary Figure 2a, c), suggesting that ZD55-IL-24 was unable to help PD-1 blockade to further improve the tumor immune microenvironment in distant tumors as well.

\section{ZD55-IL-24 cannot help PD-1 blockade to further facilitate immune cell recruitment and activation in spleens}

The spleen, where mature naive lymphocytes are maintained, collects antigen from the blood and initiates the systemic immune responses [31]. Motivated by the immune infiltration-promoting signature in distant tumors (Fig. 4a-h), we proceeded to investigate whether
ZD55-IL-24 was able to further increase immune cell recruitment and activation in spleens of the anti-PD-1treated mice. In spleens, other than an increased percentage of $\mathrm{CD}^{+} \mathrm{T}$ cells with ZD55-IL-24 or anti-PD-1-treated mice versus PBS control, there was no significant change among the different treatment groups (Fig. 5a-h), indicating that ZD55-IL-24 was unable to help PD-1 blockade to further facilitate immune cell recruitment and activation in the spleen. Likewise, we also analyzed the recruitment and activation of $T_{\text {reg }}$ cells in spleens and calculated the $T_{\text {conv }} / T_{\text {reg }}$ ratio. However, no significant difference in both $T_{\text {reg }}$ cells and $T_{\text {conv }} / T_{\text {reg }}$ ratio was observed between the treatment groups (Supplementary Figure $3 \mathrm{a}-\mathrm{c}$ ), showing that ZD55-IL-24 was unable to help PD-1 blockade to reverse the immunosuppressive milieu in the spleen.

\section{ZD55-IL-24 can help PD-1 blockade to overcome the weakness of relatively low tumor immune recognition}

Immune responses are initiated when antigen-presenting cells (APCs), especially dendritic cells (DCs), recognize antigens [31]. However, tumor cells tend to be self-origin and are inherently not very immunogenic, hence failure to be recognized by APCs is generally the major obstacle for cancer immunotherapy including PD-1 blockade therapy $[27,31]$. Thus, we finally explored the impact of combination therapy on the tumor immune recognition. Both MHC $\mathrm{II}^{+} \mathrm{CD} 11 \mathrm{c}^{-}$APCs and DCs were significantly increased in local (Fig. 6a, b) and distant (Fig. 6c, d) tumors in ZD55-IL24-treated mice, but not in anti-PD-1-treated mice, indicating that ZD55-IL-24 was able to improve tumor immune recognition in both local and distant tumors, while PD-1 blockade failed to achieve this effect. Similarly, ZD55-IL-24 treatment alone led to a small but statistically significant increase of DCs in spleens as well, despite there was no difference in $\mathrm{MHC} \mathrm{II}^{+} \mathrm{CD} 11 \mathrm{c}^{-}$APCs (Fig. 6e, f), further indicating that ZD55-IL-24 but not PD-1 blockade was able to improve tumor immune recognition in spleens. With the exception of $\mathrm{MHC} \mathrm{II}^{+} \mathrm{CD} 11 \mathrm{c}^{-}$APCs in spleens, a substantial increase of MHC $\mathrm{II}^{+} \mathrm{CD} 11 \mathrm{c}^{-}$APCs and DCs in local and distant tumors as well as spleens was observed in the combination therapy group when compared to anti-PD-1 monotherapy group, albeit no further increase compared with ZD55-IL-24 monotherapy group (Fig. 6b, d, f). Taken together, these data indicated that ZD55-IL-24 rather than PD-1 blockade was able to improve tumor immune recognition in both local and distant tumors as well as spleens, and ZD55-IL-24 could help PD-1 blockade to overcome the limitation of relatively low tumor immune recognition, contributing to the observed synergistic effect in B16-bearing immunocompetent mouse model. 
a

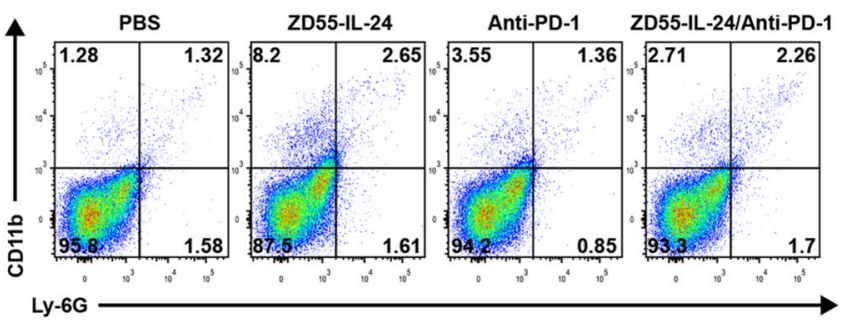

C

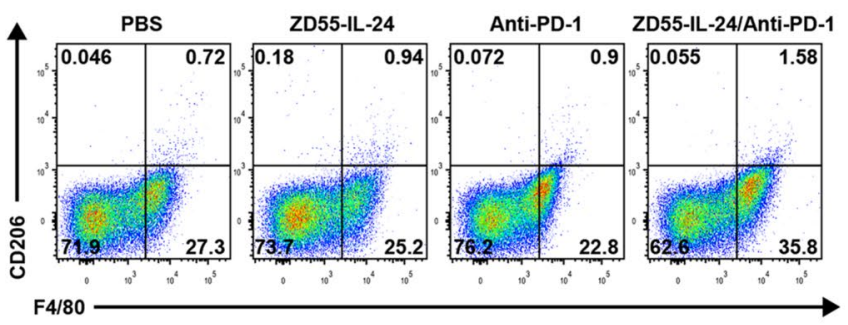

e

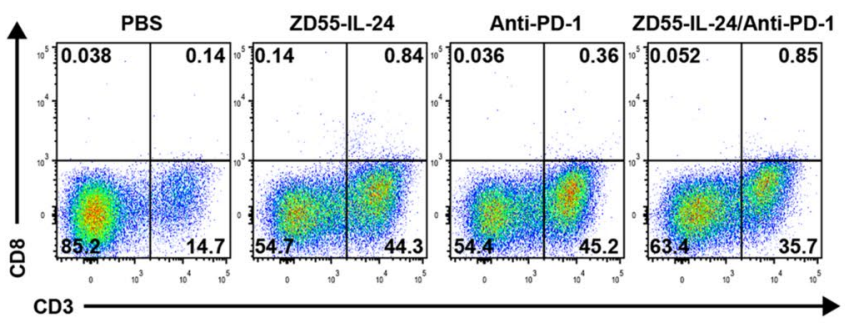

g

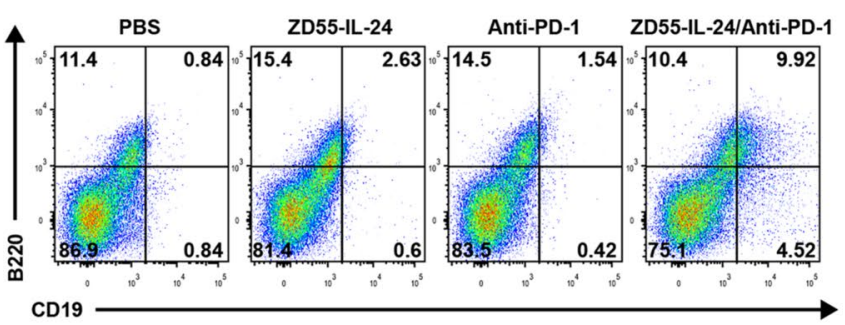

Fig. 4 ZD55-IL-24 helps PD-1 blockade to overcome the weakness of relatively low immune cell infiltration in not only local injected but also distant uninjected tumors. C57BL/6 mice were treated as indicated in Fig. 3a, and then the left flank tumors were resected from the sacrificed mice for flow cytometry analysis. Tumor immune infiltration of innate immune cells in distant tumors. a Representative flow cytometry plots of tumor-infiltrating total myeloid cells and neutrophils in distant tumors. b Representative flow cytometry plots of tumor-infiltrating NK cells and NKT cells in distant tumors. c Representative flow cytometry plots of tumor-infiltrating M1 macrophages and M2 macrophages in distant tumors. d Percentages of various b

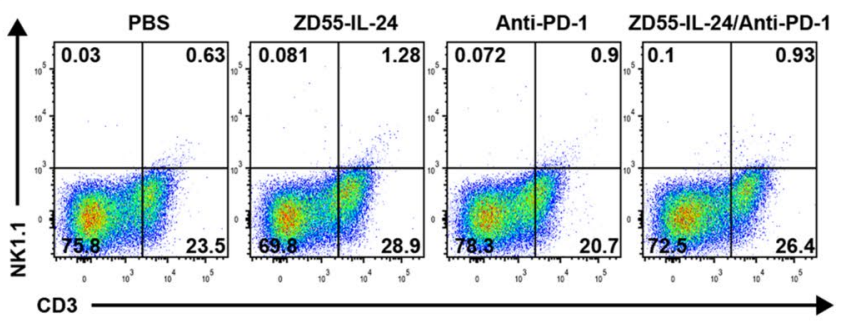

d

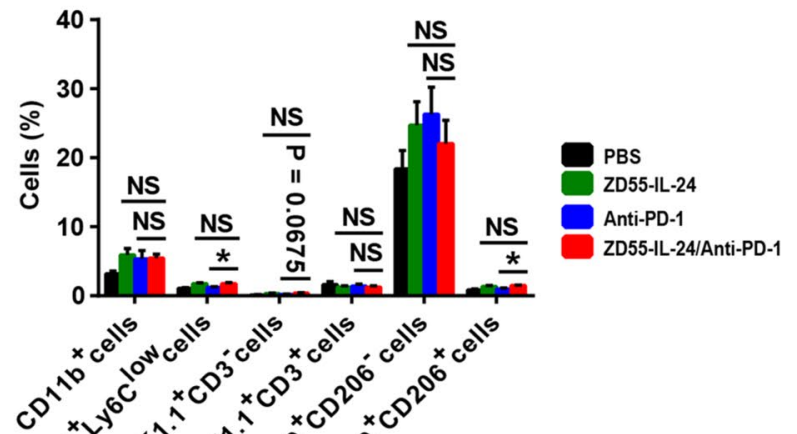

f

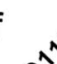

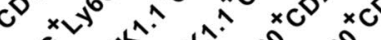<smiles>[CH-]</smiles>

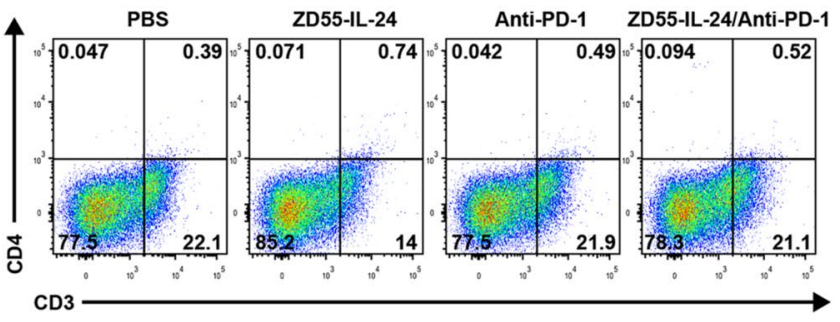

h

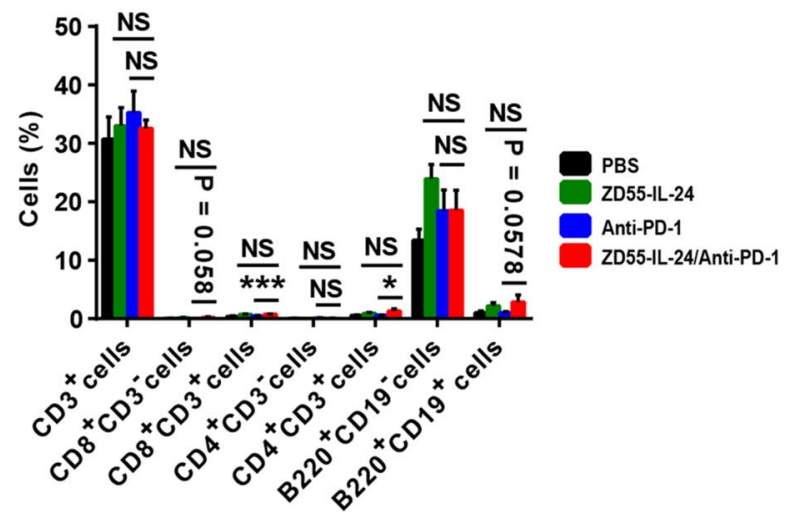

innate immune cells in distant tumors. Tumor immune infiltration of adaptive immune cells in distant tumors. e Representative flow cytometry plots of tumor-infiltrating total $\mathrm{T}$ cells, $\mathrm{CD} 8^{+} \mathrm{CD} 3^{-}$cells and $\mathrm{CD}^{+} T$ cells in distant tumors. $\mathrm{f}$ Representative flow cytometry plots of tumor-infiltrating $\mathrm{CD}^{+}{ }^{+} \mathrm{CD} 3^{-}$cells and $\mathrm{CD} 4^{+} T$ cells in distant tumors. g Representative flow cytometry plots of tumor-infiltrating plasma cells and B cells in distant tumors. $\mathbf{h}$ Percentages of various adaptive immune cells in distant tumors. Mean \pm SEM is shown. Data represent cumulative results from seven independent experiments 
a

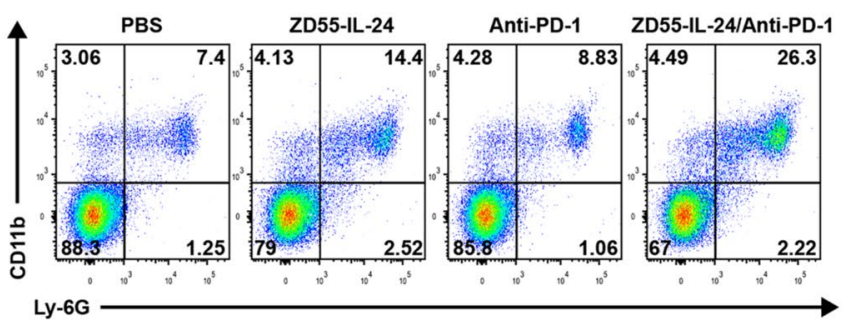

C

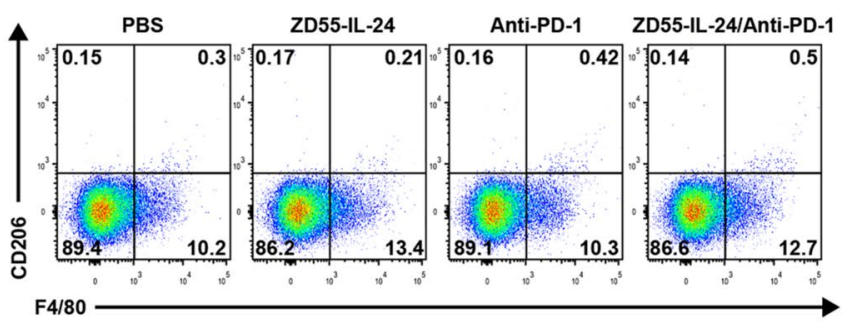

e

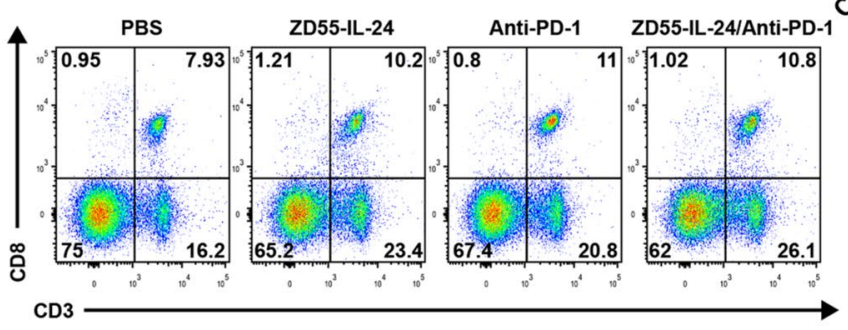

g

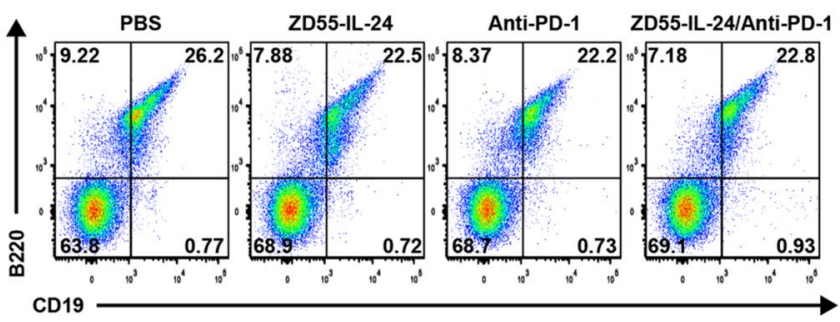

Fig. 5 ZD55-IL-24 fails to help PD-1 blockade to further facilitate immune cell recruitment and activation in spleens. C57BL/6 mice were treated as indicated in Fig. $3 \mathrm{a}$, and then the spleen cells were isolated for flow cytometry analysis. Recruitment and activation of innate immune cells in spleens. a Representative flow cytometry plots of tumor-infiltrating total myeloid cells and neutrophils in spleens. b Representative flow cytometry plots of tumor-infiltrating NK cells and NKT cells in spleens. c Representative flow cytometry plots of tumor-infiltrating M1 macrophages and M2 macrophages in spleens. b

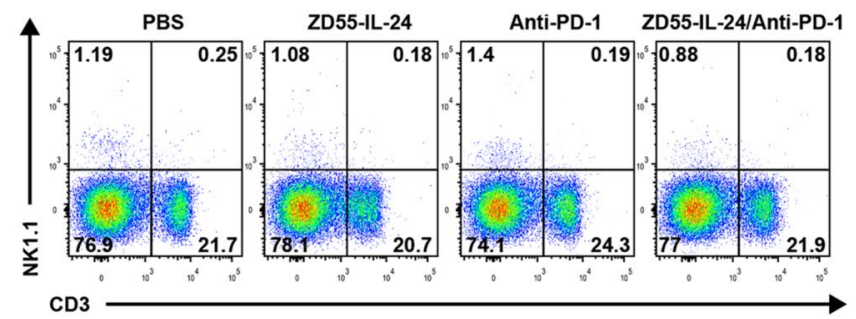

\section{d}

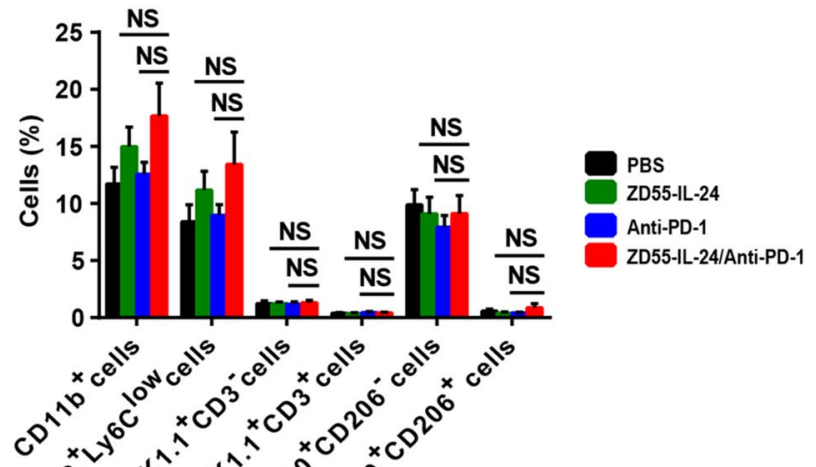

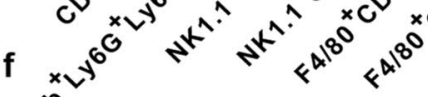

$0^{n^{n}}$

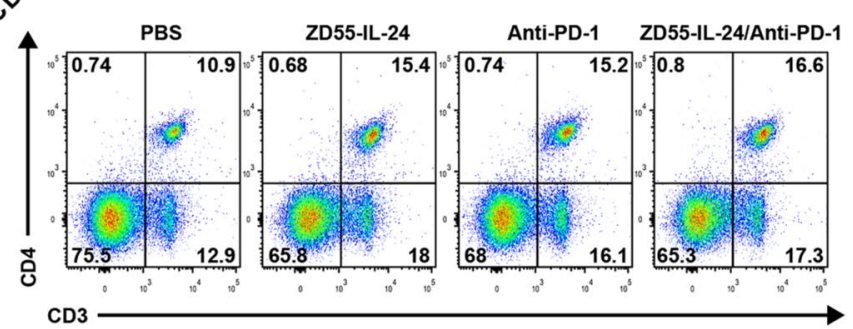

h

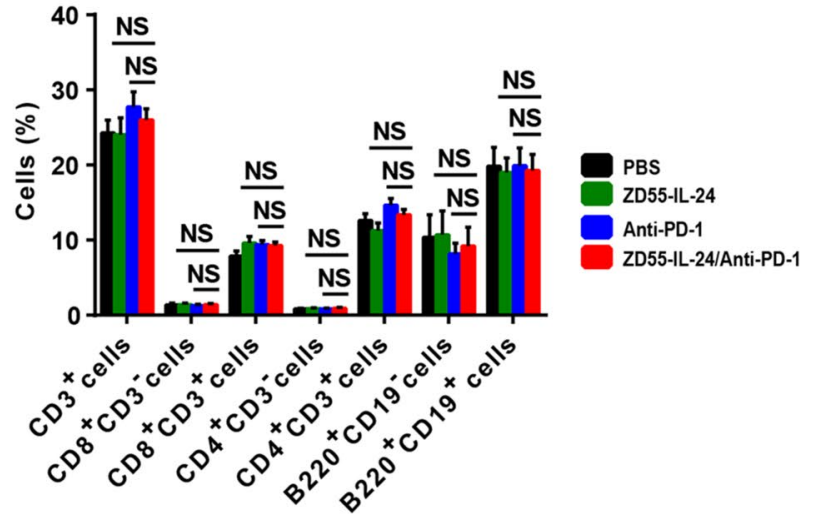

d Percentages of various innate immune cells in spleens. Recruitment and activation of adaptive immune cells in spleens. e Representative flow cytometry plots of tumor-infiltrating total $\mathrm{T}$ cells, $\mathrm{CD} 8^{+} \mathrm{CD} 3^{-}$ cells and $\mathrm{CD} 8^{+} T$ cells in spleens. f Representative flow cytometry plots of tumor-infiltrating $\mathrm{CD}^{+}{ }^{+} \mathrm{CD} 3^{-}$cells and $\mathrm{CD}^{+} T$ cells in spleens. $\mathrm{g}$ Representative flow cytometry plots of tumor-infiltrating plasma cells and B cells in spleens. $\mathbf{h}$ Percentages of various adaptive immune cells in spleens. Mean \pm SEM is shown. Data represent cumulative results from seven independent experiments 
a

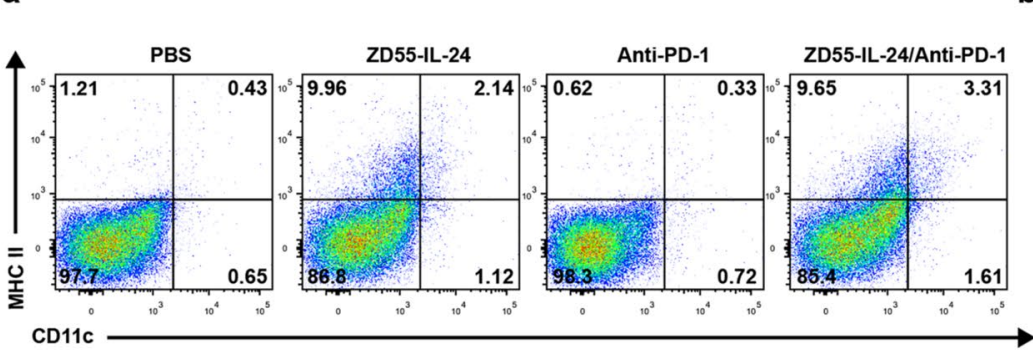

b

C
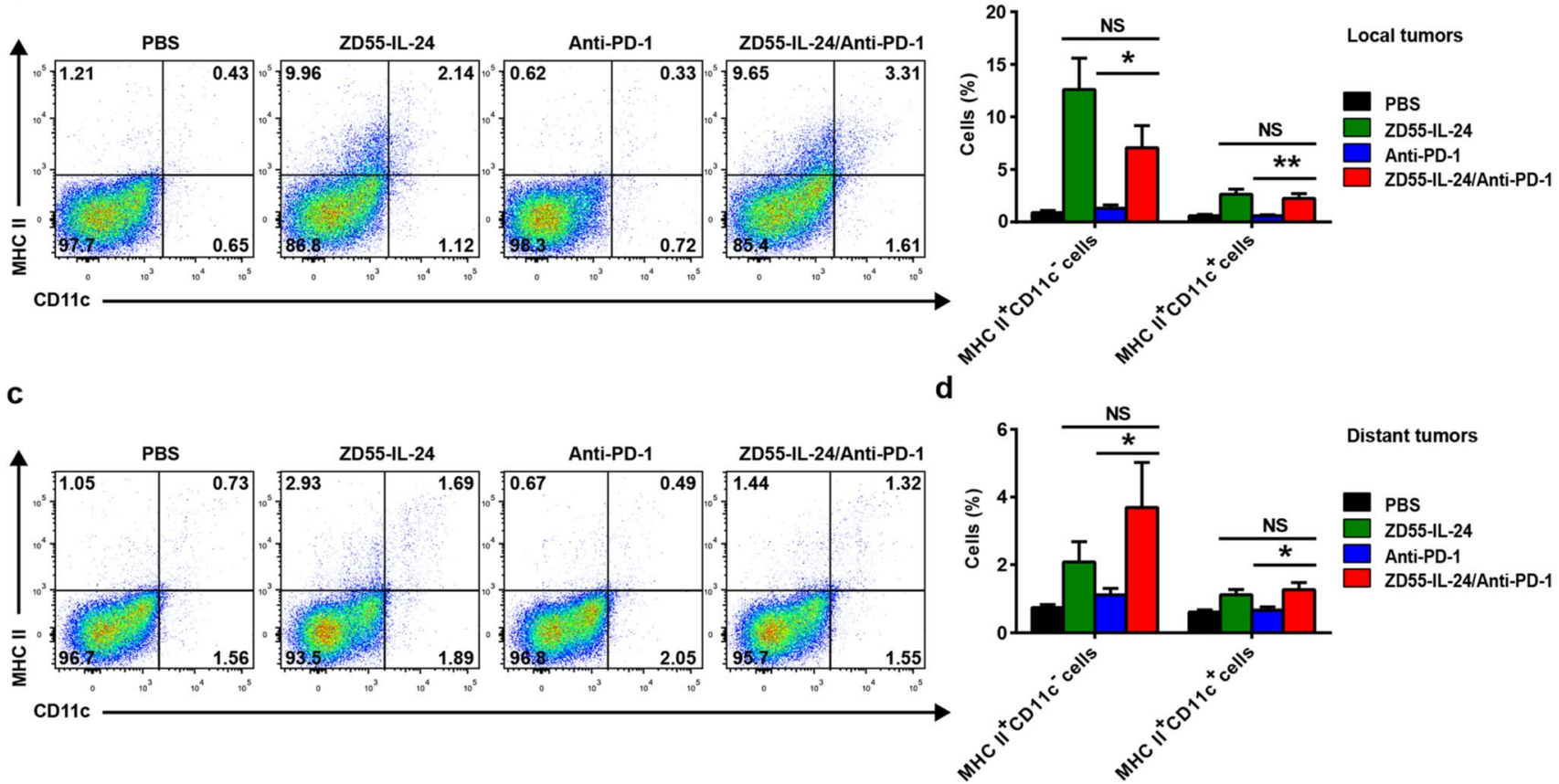

e

$\mathbf{f}$

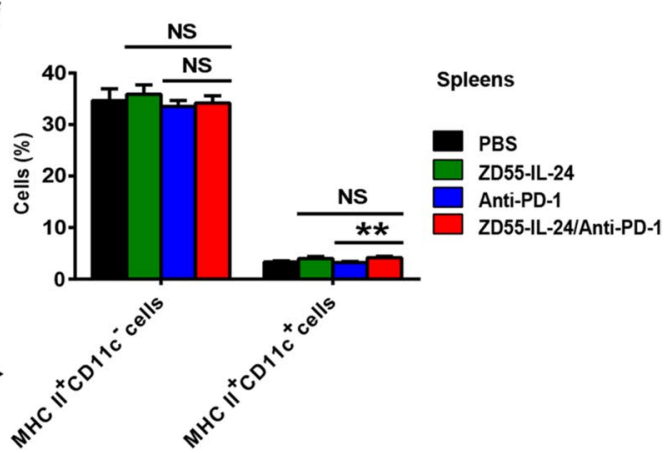

Fig. 6 ZD55-IL-24 helps PD-1 blockade to overcome the limitation of relatively low tumor immune recognition in B16-bearing immunocompetent mouse model. C57BL/6 mice were treated as indicated in Fig. 3a, and then the tumor and spleen cells were isolated for flow cytometry analysis. a Representative flow cytometry plots of tumorinfiltrating $\mathrm{MHC} \mathrm{II}^{+} \mathrm{CD} 11 \mathrm{c}^{-}$APCs and DCs $\left(\mathrm{MHC} \mathrm{II}^{+} \mathrm{CD} 11 \mathrm{c}^{+}\right)$in local tumors. b Percentages of MHC $\mathrm{II}^{+} \mathrm{CD} 11 \mathrm{c}^{-} \mathrm{APCs}$ and DCs in

\section{Discussion}

There is a growing body of evidence to support combinatorial approaches that merge immune checkpoint blockade therapy with oncolytic virotherapy [32-36]. ZD55-IL-24 is an armed oncolytic adenovirus type 5 analogous but superior to the famous ONYX-015 and H101 (Oncorine). ONYX015 has been evaluated in several clinical trials, though limited responses were reported and clinical development was halted in 2003 [14]. H101 has been approved for clinical use for head and neck cancer in China in 2005 [14]. Here, we demonstrate for the first time that our ZD55-IL-24 has synergistic activity with anti-PD-1 therapy in B16-bearing local tumors. c Representative flow cytometry plots of tumor-infiltrating MHC $\mathrm{II}^{+} \mathrm{CD} 11 \mathrm{c}^{-}$APCs and DCs in distant tumors. d Percentages of $\mathrm{MHC} \mathrm{II}^{+} \mathrm{CD} 11 \mathrm{c}^{-}$APCs and DCs in distant tumors. e Representative flow cytometry plots of $\mathrm{MHC} \mathrm{II}^{+} \mathrm{CD} 11 \mathrm{c}^{-}$APCs and DCs in spleens. f Percentages of MHC $\mathrm{II}^{+} \mathrm{CD} 11 \mathrm{c}^{-}$APCs and DCs in spleens. Mean \pm SEM is shown. Data represent cumulative results from seven independent experiments

immunocompetent mouse model. These data support further evaluation of ZD55-IL-24 as a combination partner in clinical trials.

In this study, we found that anti-PD-1 treatment in fact had no apparent effect on tumor immune infiltration and recognition. ZD55-IL-24 treatment, however, was able to greatly promote tumor immune infiltration and recognition at the injected tumor site and in regression of distant tumors as well as in spleens. These results indicated that ZD55IL-24 can help PD-1 blockade to overcome the limitation of relatively low tumor immune infiltration and recognition. On the other hand, PD-1 blockade is primarily believed to inhibit various effector immune cells inactivation in the 
effector phase within tissue and tumors, and thus prolonging the killing time of immune system to tumor cells [37]. However, ZD55-IL-24 fails to do this. Therefore, PD-1 blockade can help ZD55-IL-24 to overcome the limitation of relatively short tumor killing time. In this way, ZD55-IL-24 and PD-1 blockade achieve their synergistic therapeutic effect (Fig. 7).

The synergistic antitumor effect between oncolytic viruses and PD-1 blockade in B16-bearing immunocompetent mouse model has been well-documented [38-42]. Consistent with these reports, our results indeed demonstrate that ZD55-IL-24 synergizes with PD-1 blockade to reject not only local injected tumors but also distant uninjected tumors in B16-bearing immunocompetent mouse model. It is generally thought that the oncolytic virus infection can result in immunogenic tumor cell death and release the essential elements such as tumor-associated antigens, viral pathogen-associated molecular patterns, cellular dangerassociated molecular pattern signals and cytokines such as type I interferons, which result in the generation of antitumor immunity [14, 23, 32, 43]. Thus, the induction of antitumor immunity by oncolytic viruses was thought to depend on successful viral infection, induction of immunogenic tumor cell death, and release of the essential elements. However, our recent research confirmed that ZD55-IL-24 can induce antitumor immunity in B16-bearing immunocompetent mouse model in fact not due to its ability to lyse tumor cells and release the essential elements, but due to its ability to turn the tumor cells from the unrecognizable "self" state into the recognizable "nonself" state without tumor cell death [44]. Hence, our previous and current results together
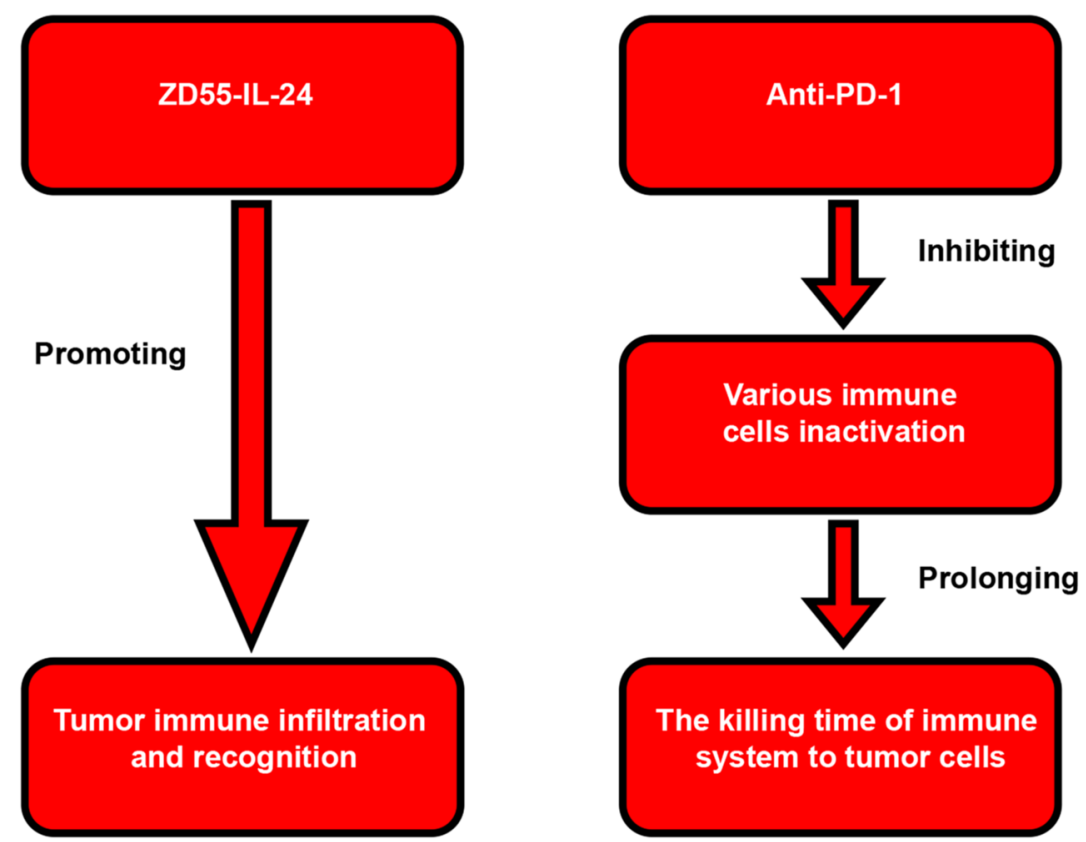

Helping anti-PD-1 to overcome the weakness of relatively low tumor immune infiltration and recognition
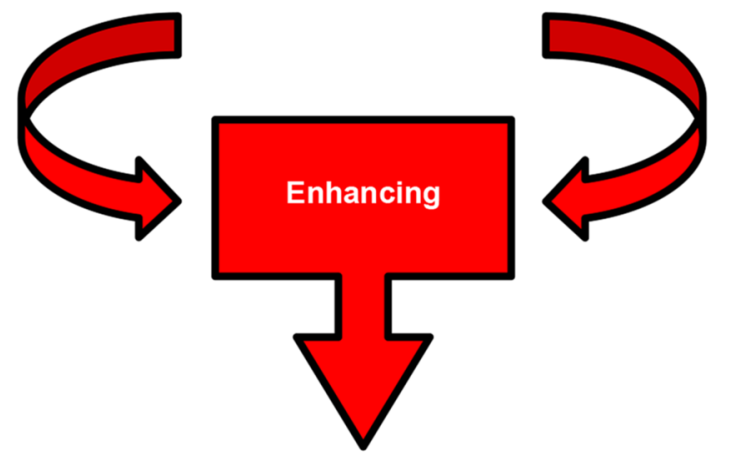

Helping ZD55-IL-24 to overcome the weakness of relatively short tumor immune killing time

The antitumor efficacy

Fig. 7 Mechanistic model of combination therapy with ZD55-IL-24 and PD-1 blockade 
indicate that ZD55-IL-24 can turn the tumor cells from the "self" state into the "nonself" state without tumor cell death, thus make the tumor cells easy to be recognized by original host immune system, finally help PD-1 blockade to reject melanomas in B16-bearing immunocompetent mouse model. The synergetic mechanism between ZD55-IL-24 and PD-1 blockade is somewhat different from the synergetic mechanism which we previously thought. Notably, we here find that synergy is also observed even though the oncolytic virus is unable to successfully infect and directly lyse tumor cells, suggesting that the synergistic effect between oncolytic viruses and PD-1 blockade probably depends on the capability of oncolytic viruses to turn the tumor cells from the "self" state into the "nonself" state, rather than the capability of oncolytic viruses to lyse tumor cells.

Our study does present several limitations. First of all, immunologic assessments of oncolytic adenoviruses are known to be challenging as good model systems that allow for both viral replication and immunologic analyses are limited. Indeed, our results indicated that ZD55-IL-24 is unable to successfully infect and express exogenous IL-24 gene in B16 cells, the IL-24 gene harbored in ZD55-IL-24 viral genome in fact plays no role in B16-bearing immunocompetent mouse model [44]. Therefore, the observed synergistic therapeutic effect between ZD55-IL-24 and PD-1 blockade here is practically caused only by the viral vector. However, IL-24 also displays direct and indirect antitumor activity through induction of autophagy and cancer-specific apoptosis, stimulation of an antitumor immune response, inhibition of angiogenesis, and sensitization of cancer cells to radiation-, chemotherapy- and antibody-induced killing [45]. Thus, the synergistic antitumor effect between IL-24 and PD-1 blockade is unable to be observed in current study. However, it is reasonable to surmise that a more robust synergistic effect between ZD55-IL-24 and PD-1 blockade will be observed when the IL-24 gene works. Second, it is well known that most murine tissues are not supportive of human adenovirus replication. Data obtained from mouse model are perhaps different from patient situation. These challenges, however, can be addressed in clinical trials. Hence, further investigation in patients may yield important information.

In our study, we observed that the anti-melanoma efficacy of ZD55-IL-24 in local tumors is far higher than that of anti-PD-1 antibody in B16-bearing immunocompetent mouse model (Figs. 1a-e and 3b), indicating ZD55-IL-24 has an obvious advantage in antitumor efficacy. Besides the much higher antitumor efficacy, another advantage of ZD55-IL-24 is the far lower production cost compared with anti-PD-1 antibody (the cost of ZD55-IL-24 in this study is less than $\$ 1$, but the cost of anti-PD-1 antibody is more than $\$ 1000$ ). The manufacturing process of ZD55IL-24, which is based on viral replication and purification, is much simpler; in contrast, anti-PD-1 antibody has to be produced via much more complex process, which is based on protein expression and purification. Less expensive production cost may help to reduce drug price. In addition, the dramatic response of anti-PD-1 therapy is often restricted to a minority of patients [3, 5, 37], yet ZD55-IL-24 therapy appears less individual variance (data not shown). Nevertheless, ZD55-IL-24 does present some limitations. Since it must be administered intratumorally at present, ZD55-IL-24 is only suitable for treating those few tumors with visible lesions such as melanoma and in fact difficult to be used to treat the vast majority of tumors in clinic. Albeit with far lower efficacy and response rate as well as much higher cost, anti-PD-1 antibody can be administered systemically and thus can be theoretically used to treat almost all tumors, which is an incomparable advantage. Moreover, ZD55-IL-24 still presents some limitations even for melanoma treatment. For example, the dramatic anti-melanoma efficacy of ZD55-IL-24 is merely confined to local tumors, but substantially reduced in distant tumors and extremely lower than anti-PD-1 antibody (Fig. 3b, c, f-k). Unlike ZD55-IL-24, the anti-melanoma efficacy of anti-PD-1 antibody is identical in both local and distant tumors. ZD55-IL-24 and PD-1 blockade can help each other overcome their limitations. Therefore, although ZD55-IL-24 alone or PD-1 blockade alone might be successful in melanoma therapy, combination therapy might be much more reliable in future clinical therapy.

Supplementary information The online version contains supplementary material available at https://doi.org/10.1007/s00262-021-02946-z.

Acknowledgments We would like to thank professor Hong-Bin Ji and Wei-Guo Zou (Shanghai Institute of Biochemistry and Cell Biology, Shanghai Institutes for Biological Sciences, Chinese Academy of Sciences) for their helpful discussion.

Author contributions H.-J.H. designed the studies with the help of X.Y.L., generated most of the data along with X.L. and interpreted all the results. H.-Y.W., J.X. and J.-Q.H., helped perform animal experiments. H.-J.H. wrote the manuscript and X.-Y.L. edited the manuscript; H.L.L. and J.-F.G. provided important advice for this study; A.-M.N. and L.-Y.S. provided ZD55-IL-24 and cell lines, respectively.

Funding This work was supported by National Natural Science Foundation of China (81372453, 81572999, 31701220), Sichuan Science and Technology Project (2013ZZ0004), Shanghai Institutes for Biological Science, Chinese Academy of Sciences and Sichuan Huiyang Life Science and Technology Corp. Research Program (Y363S21763), and Grant from the Sino-American Joint Laboratory between Conba Group and Zhejiang Sci-Tech University.

Availability of data and material Correspondence and requests for data and materials should be addressed to X.-Y.L., H.-J.H., or A.-M.N. ZD55-IL-24 was supplied by Yuansong Biotech Inc. under a material transfer agreement with Shanghai Institutes for Biological Sciences, Chinese Academy of Sciences, China. 


\section{Declarations}

Ethics approval and consent to participate All animal experiments were approved by the Institutional Animal Care and Use Committee (IACUC) of Institute of Biochemistry and Cell Biology, Shanghai Institutes for Biological Sciences, Chinese Academy of Sciences.

Consent for publication I would like to declare that the manuscript is approved by all authors for publication.

Conflict of interest X.-Y.L., J.-F.G. and L.-Y.S. are inventors on a patent for the construction and application of ZD55-IL-24 (US Patent and Trademark Office, 20090117643A1). The other authors declare no competing financial interests.

Open Access This article is licensed under a Creative Commons Attribution 4.0 International License, which permits use, sharing, adaptation, distribution and reproduction in any medium or format, as long as you give appropriate credit to the original author(s) and the source, provide a link to the Creative Commons licence, and indicate if changes were made. The images or other third party material in this article are included in the article's Creative Commons licence, unless indicated otherwise in a credit line to the material. If material is not included in the article's Creative Commons licence and your intended use is not permitted by statutory regulation or exceeds the permitted use, you will need to obtain permission directly from the copyright holder. To view a copy of this licence, visit http://creativecommons.org/licenses/by/4.0/.

\section{References}

1. Zhu L, Kalimuthu S, Gangadaran P, Oh JM, Lee HW, Baek SH, Jeong SY, Lee SW, Lee J, Ahn BC (2017) Exosomes derived from natural killer cells exert therapeutic effect in melanoma. Theranostics 7(10):2732-2745. https://doi.org/10.7150/thno.18752

2. Garbe C, Eigentler TK, Keilholz U, Hauschild A, Kirkwood JM (2011) Systematic review of medical treatment in melanoma: current status and future prospects. Oncologist 16(1):5-24. https:// doi.org/10.1634/theoncologist.2010-0190

3. Luke JJ, Flaherty KT, Ribas A, Long GV (2017) Targeted agents and immunotherapies: optimizing outcomes in melanoma. Nat Rev Clin Oncol 14:463-482. https://doi.org/10.1038/nrclinonc. 2017.43

4. Sullivan RJ, Flaherty KT (2015) Immunotherapy: anti-PD-1 therapies-a new first-line option in advanced melanoma. Nat Rev Clin Oncol 12(11):625-626. https://doi.org/10.1038/nrclinonc.2015. 170

5. Moynihan KD, Opel CF, Szeto GL, Tzeng A, Zhu EF, Engreitz JM, Williams RT, Rakhra K, Zhang MH, Rothschilds AM, Kumari S, Kelly RL, Kwan BH, Abraham W, Hu K, Mehta NK, Kauke MJ, Suh H, Cochran JR, Lauffenburger DA, Wittrup KD, Irvine DJ (2016) Eradication of large established tumors in mice by combination immunotherapy that engages innate and adaptive immune responses. Nat Med 22(12):1402-1410. https://doi.org/ $10.1038 / \mathrm{nm} .4200$

6. Gao L, Zhang C, Gao D, Liu H, Yu X, Lai J, Wang F, Lin J, Liu Z (2016) Enhanced anti-tumor efficacy through a combination of integrin $\alpha v \beta 6$-targeted photodynamic therapy and immune checkpoint inhibition. Theranostics 6(5):627-637. https://doi.org/10. 7150/thno. 14792

7. Kim JE, Patel MA, Mangraviti A, Kim ES, Theodros D, Velarde E, Liu A, Sankey EW, Tam A, Xu H, Mathios D, Jackson CM, Harris-Bookman S, Garzon-Muvdi T, Sheu M, Martin AM, Tyler BM, Tran PT, Ye X, Olivi A, Taube JM, Burger PC, Drake CG,
Brem H, Pardoll DM, Lim M (2017) Combination therapy with anti-PD-1, anti-TIM-3, and focal radiation results in regression of murine gliomas. Clin Cancer Res 23(1):124-136. https://doi.org/ 10.1158/1078-0432.CCR-15-1535

8. Guo Z, Wang H, Meng F, Li J, Zhang S (2015) Combined Trabectedin and anti-PD1 antibody produces a synergistic antitumor effect in a murine model of ovarian cancer. J Transl Med 13:247. https://doi.org/10.1186/s12967-015-0613-y

9. Buchbinder EI, Hodi FS (2016) Melanoma in 2015: Immunecheckpoint blockade-durable cancer control. Nat Rev Clin Oncol 13(2):77-78. https://doi.org/10.1038/nrclinonc.2015.237

10. Ribas A, Robert C, Hodi FS, Wolchok JD, Hwu WJ (2015) Association of response to programmed death receptor 1 (PD-1) blockade with pembrolizumab (MK-3475) with an interferon-inflammatory immune gene signature. J Clin Oncol 33(2):141-147. https:// doi.org/10.1002/pi.1995.210370209

11. Puzanov I, Milhem MM, Minor D, Hamid O, Li A, Chen L, Chastain M, Gorski KS, Anderson A, Chou J, Kaufman HL, Andtbacka RH (2016) Talimogene Laherparepvec in combination with Ipilimumab in previously untreated, unresectable stage IIIB-IV melanoma. J Clin Oncol 34(22):2619-2626. https://doi.org/10. 1200/JCO.2016.67.1529

12. Russell SJ, Peng KW, Bell JC (2012) Oncolytic virotherapy. Nat Biotechnol 30(7):658-670. https://doi.org/10.1038/nbt.2287

13. Zhang ZL, Zou WG, Luo CX, Li BH, Wang JH, Sun LY, Qian QJ, Liu XY (2003) An armed oncolytic adenovirus system, ZD55-gene, demonstrating potent antitumoral efficacy. Cell Res 13(6):481-489. https://doi.org/10.1038/sj.cr.7290191

14. Kaufman HL, Kohlhapp FJ, Zloza A (2015) Oncolytic viruses: a new class of immunotherapy drugs. Nat Rev Drug Discov 14(9):642-662. https://doi.org/10.1038/nrd4663

15. Wang Y, Hallden G, Hill R, Anand A, Liu TC, Francis J, Brooks G, Lemoine N, Kirn D (2003) E3 gene manipulations affect oncolytic adenovirus activity in immunocompetent tumor models. Nat Biotechnol 21(11):1328-1335. https://doi.org/10.1038/nbt887

16. Zhao L, Gu J, Dong A, Zhang Y, Zhong L, He L, Wang Y, Zhang J, Zhang Z, Huiwang J, Qian Q, Qian C, Liu X (2005) Potent antitumor activity of oncolytic adenovirus expressing mda-7/IL-24 for colorectal cancer. Hum Gene Ther 16(7):845-858. https://doi.org/ 10.1089/hum.2005.16.845

17. Liu XY, Pestka S, Shi YF (2013) Recent advances in cancer research and therapy. Tsinghua University Press, Beijing

18. Qian W, Liu J, Tong Y, Yan S, Yang C, Yang M, Liu X (2008) Enhanced antitumor activity by a selective conditionally replicating adenovirus combining with MDA-7/interleukin-24 for B-lymphoblastic leukemia via induction of apoptosis. Leukemia 22(2):361-369. https://doi.org/10.1038/sj.leu.2405034

19. Yuan S, Fang X, Xu Y, Ni A, Liu XY, Chu L (2016) An oncolytic adenovirus that expresses the HAb18 and interleukin 24 genes exhibits enhanced antitumor activity in hepatocellular carcinoma cells. Oncotarget 7(37):60491-60502. https://doi.org/10.18632/ oncotarget. 11134

20. Zhong S, Yu D, Wang Y, Qiu S, Wu S, Liu XY (2010) An armed oncolytic adenovirus ZD55-IL-24 combined with ADM or DDP demonstrated enhanced antitumor effect in lung cancer. Acta Oncol 49(1):91-99. https://doi.org/10.3109/02841860903246557

21. Young L, Sung J, Stacey G, Masters JR (2010) Detection of mycoplasma in cell cultures. Nat Protoc 5(5):929-934. https://doi.org/ 10.1038/nprot.2010.43

22. Kilkenny C, Browne WJ, Cuthill IC, Emerson M, Altman DG (2010) Improving bioscience research reporting: the ARRIVE guidelines for reporting animal research. PLoS Biol 8(6):e1000412. https://doi.org/10.1371/journal.pbio.1000412

23. Zamarin D, Holmgaard RB, Subudhi SK, Park JS, Mansour M, Palese P, Merghoub T, Wolchok JD, Allison JP (2014) Localized oncolytic virotherapy overcomes systemic tumor resistance 
to immune checkpoint blockade immunotherapy. Sci Transl Med 6(226):226-232. https://doi.org/10.1126/scitranslmed.3008095

24. Borst J, Ahrends T, Bąbała N, Melief CJM, Kastenmüller W (2018) $\mathrm{CD}^{+} \mathrm{T}$ cell help in cancer immunology and immunotherapy. Nat Rev Immunol 18(10):635-647. https://doi.org/10. 1038/s41577-018-0044-0

25. Mantovani A, Marchesi F, Malesci A, Laghi L, Allavena P (2017) Tumour-associated macrophages as treatment targets in oncology. Nat Rev Clin Oncol 14:399-416. https://doi.org/10.1038/ nrclinonc.2016.217

26. Vivier E, Ugolini S, Blaise D, Chabannon C, Brossay L (2012) Targeting natural killer cells and natural killer T cells in cancer. Nat Rev Immunol 12(4):239-252. https://doi.org/10.1038/nri3174

27. Wculek SK, Cueto FJ, Mujal AM, Melero I, Krummel MF, Sancho D (2020) Dendritic cells in cancer immunology and immunotherapy. Nat Rev Immunol 20(1):7-24. https://doi.org/10.1038/ s41577-019-0210-Z

28. Ohue Y, Nishikawa H (2019) Regulatory $T\left(\mathrm{~T}_{\text {reg }}\right)$ cells in cancer: can $\mathrm{T}_{\text {reg }}$ cells be a new therapeutic target? Cancer Sci 110(7):2080-2089. https://doi.org/10.1111/cas.14069

29. Tanaka A, Sakaguchi S (2017) Regulatory T cells in cancer immunotherapy. Cell Res 27(1):109-118. https://doi.org/10.1038/cr. 2016.151

30. Kumar P, Bhattacharya P, Prabhakar BS (2018) A comprehensive review on the role of co-signaling receptors and $\mathrm{T}_{\text {reg }}$ homeostasis in autoimmunity and tumor immunity. J Autoimmun 95:77-99. https://doi.org/10.1016/j.jaut.2018.08.007

31. Murphy K (2012) Janeway's immunobiology, 8th edn. Garland Science, London

32. Bourgeois-Daigneault MC, Roy DG, Aitken AS, El Sayes N, Martin NT, Varette O, Falls T, St-Germain LE, Pelin A, Lichty BD, Stojdl DF, Ungerechts G, Diallo JS, Bell JC (2018) Neoadjuvant oncolytic virotherapy before surgery sensitizes triple-negative breast cancer to immune checkpoint therapy. Sci Transl Med 10(422):eaao1641. https://doi.org/10.1126/scitranslmed.aao1641

33. Hardcastle J, Mills L, Malo CS, Jin F, Kurokawa C, Geekiyanage H, Schroeder M, Sarkaria J, Johnson AJ, Galanis E (2017) Immunovirotherapy with measles virus strains in combination with antiPD-1 antibody blockade enhances antitumor activity in glioblastoma treatment. Neuro Oncol 19(4):493-502. https://doi.org/10. 1093/neuonc/now179

34. Liu Z, Ravindranathan R, Kalinski P, Guo ZS, Bartlett DL (2017) Rational combination of oncolytic vaccinia virus and PD-L1 blockade works synergistically to enhance therapeutic efficacy. Nat Commun 8:14754. https://doi.org/10.1038/ncomms14754

35. Samson A, Scott KJ, Taggart D, West EJ, Wilson E, Nuovo GJ, Thomson S, Corns R, Mathew RK, Fuller MJ, Kottke TJ, Thompson JM, Ilett EJ, Cockle JV, van Hille P, Sivakumar G, Polson ES, Turnbull SJ, Appleton ES, Migneco G, Rose AS, Coffey MC, Beirne DA, Collinson FJ, Ralph C, Alan Anthoney D, Twelves CJ, Furness AJ, Quezada SA, Wurdak H, Errington-Mais F, Pandha H, Harrington KJ, Selby PJ, Vile RG, Griffin SD, Stead LF, Short SC, Melcher AA (2018) Intravenous delivery of oncolytic reovirus to brain tumor patients immunologically primes for subsequent checkpoint blockade. Sci Transl Med 10(422):eaam7577. https:// doi.org/10.1126/scitranslmed.aam7577

36. Cockle JV, Rajani K, Zaidi S, Kottke T, Thompson J, Diaz RM, Shim K, Peterson T, Parney IF, Short S, Selby P, Ilett E, Melcher A, Vile R (2016) Combination viroimmunotherapy with checkpoint inhibition to treat glioma, based on location-specific tumor profiling. Neuro Oncol 18(4):518-527. https://doi.org/10.1093/ neuonc/nov173
37. Boutros C, Tarhini A, Routier E, Lambotte O, Ladurie FL, Carbonnel $\mathrm{F}$, Izzeddine $\mathrm{H}$, Marabelle $\mathrm{A}$, Champiat $\mathrm{S}$, Berdelou A, Lanoy E, Texier M, Libenciuc C, Eggermont AM, Soria JC, Mateus C, Robert C (2016) Safety profiles of anti-CTLA-4 and anti-PD-1 antibodies alone and in combination. Nat Rev Clin Oncol 13(8):473-486. https://doi.org/10.1038/nrclinonc.2016.58

38. Rajani K, Parrish C, Kottke T, Thompson J, Zaidi S, Ilett L, Shim KG, Diaz RM, Pandha H, Harrington K, Coffey M, Melcher A, Vile R (2016) Combination therapy with reovirus and anti-PD-1 blockade controls tumor growth through innate and adaptive immune responses. Mol Ther 24(1):166-174. https://doi.org/10. 1038/mt.2015.156

39. Quetglas JI, Labiano S, Aznar M, Bolaños E, Azpilikueta A, Rodriguez I, Casales E, Sánchez-Paulete AR, Segura V, Smerdou C, Melero I (2015) Virotherapy with a semliki forest virus-based vector encoding IL12 synergizes with PD-1/PD-L1 blockade. Cancer Immunol Res 3(5):449-454. https://doi.org/10.1158/2326-6066. Cir-14-0216

40. Cervera-Carrascon V, Siurala M, Santos JM, Havunen R, Tähtinen S, Karell P, Sorsa S, Kanerva A, Hemminki A (2018) TNFa and IL-2 armed adenoviruses enable complete responses by anti-PD-1 checkpoint blockade. Oncoimmunology 7(5):e1412902. https:// doi.org/10.1080/2162402x.2017.1412902

41. Ilett E, Kottke T, Thompson J, Rajani K, Zaidi S, Evgin L, Coffey M, Ralph C, Diaz R, Pandha H, Harrington K, Selby P, Bram R, Melcher A, Vile R (2017) Prime-boost using separate oncolytic viruses in combination with checkpoint blockade improves antitumour therapy. Gene Ther 24(1):21-30. https://doi.org/10.1038/ gt. 2016.70

42. Tähtinen S, Feola S, Capasso C, Laustio N, Groeneveldt C, Ylösmäki EO, Ylösmäki L, Martins B, Fusciello M, Medeot M, Tagliamonte M, Chiaro J, Hamdan F, Peltonen K, Ranki T, Buonaguro L, Cerullo V (2020) Exploiting preexisting immunity to enhance oncolytic cancer immunotherapy. Cancer Res 80(12):2575-2585. https://doi.org/10.1158/0008-5472. Can-19-2062

43. Harrington K, Freeman DJ, Kelly B, Harper J, Soria JC (2019) Optimizing oncolytic virotherapy in cancer treatment. Nat Rev Drug Discov 18(9):689-706. https://doi.org/10.1038/ s41573-019-0029-0

44. Hu HJ, Liang X, Li HL, Du CM, Hao JL, Wang HY, Gu JF, Ni AM, Sun LY, Xiao J, Hu JQ, Yuan H, Dai YS, Jin XT, Zhang KJ, Liu XY (2020) The armed oncolytic adenovirus ZD55-IL-24 eradicates melanoma by turning the tumor cells from the selfstate into the nonself-state besides direct killing. Cell Death Dis 11(11):1022. https://doi.org/10.1038/s41419-020-03223-0

45. Dash R, Bhutia SK, Azab B, Su ZZ, Quinn BA, Kegelmen TP, Das SK, Kim K, Lee SG, Park MA, Yacoub A, Rahmani M, Emdad L, Dmitriev IP, Wang XY, Sarkar D, Grant S, Dent P, Curiel DT, Fisher PB (2010) Mda-7/IL-24: a unique member of the IL-10 gene family promoting cancer-targeted toxicity. Cytokine Growth Factor Rev 21(5):381-391. https://doi.org/10.1016/j.cytogfr.2010. 08.004

Publisher's Note Springer Nature remains neutral with regard to jurisdictional claims in published maps and institutional affiliations. 